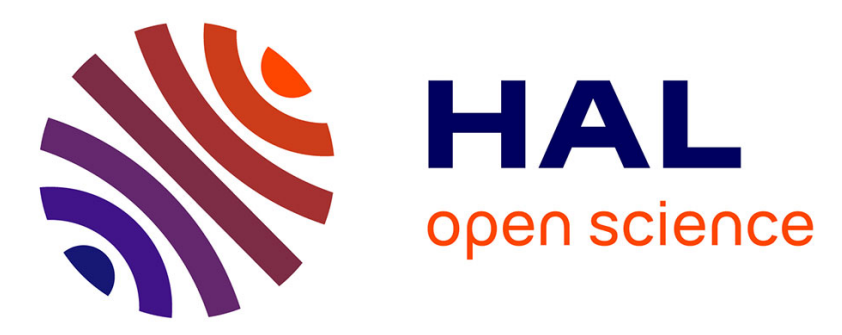

\title{
Absence of MHC class II on cDC1 dendritic cells triggers fatal autoimmunity to a cross-presented self-antigen
}

Christian Wohn, Valentin Le Guen, Odessa Voluzan, Frédéric Fiore, Sandrine Henri, Bernard Malissen

\section{To cite this version:}

Christian Wohn, Valentin Le Guen, Odessa Voluzan, Frédéric Fiore, Sandrine Henri, et al.. Absence of MHC class II on cDC1 dendritic cells triggers fatal autoimmunity to a cross-presented self-antigen. Sci. Immunol, 2020, 5. hal-03013454

\section{HAL Id: hal-03013454 https://hal.science/hal-03013454}

Submitted on 23 Nov 2020

HAL is a multi-disciplinary open access archive for the deposit and dissemination of scientific research documents, whether they are published or not. The documents may come from teaching and research institutions in France or abroad, or from public or private research centers.
L'archive ouverte pluridisciplinaire HAL, est destinée au dépôt et à la diffusion de documents scientifiques de niveau recherche, publiés ou non, émanant des établissements d'enseignement et de recherche français ou étrangers, des laboratoires publics ou privés. 


\section{Absence of MHC class II on CDC1 dendritic cells triggers fatal autoimmunity to a cross-presented self-antigen}

\author{
Christian Wohn ${ }^{1}$, Valentin Le Guen ${ }^{1}$, Odessa Voluzan ${ }^{1}$, Frédéric Fiore ${ }^{2}$, \\ Sandrine Henri ${ }^{1 *}{ }^{\dagger}$, Bernard Malissen ${ }^{1,2 *}{ }^{\dagger}$
}

Conventional dendritic cells expressing the XCR1 chemokine receptor (CDC1s) excel at cross-presentation. Here, we developed and used a mouse model in which a Cre recombinase is expressed under the control of the Xcr 1 gene while preserving XCR1 expression. We used it to generate mice with conditional deletion of MHC class II (MHCII) molecules on CDC1s. By preventing CDC1s to receive suppressive regulatory T cell inputs via MHCII-restricted interactions, the objective of the present study was to gauge whether MHCII-deficient CDC1s lose their capacity of tolerizing autoreactive $\mathrm{CD}^{+} \mathrm{T}$ cells. Whereas $\mathrm{MHCII}^{+} \mathrm{CDC1}$ readily cross-tolerized strongly autoreactive $\mathrm{CD} 8^{+} \mathrm{T}$ cells specific for a keratinocyte-derived self-antigen, MHCII-deficient CDC1s converted them into potent effectors capable of triggering a fast-onset lethal autoimmunity associated with severe skin histopathological manifestations. Preventing egress of such pathogenic self-reactive $\mathrm{CD}^{+} \mathrm{T}$ cell effectors from the cutaneous draining lymph nodes abrogated the autoimmune condition. Therefore, our results revealed that the cross-tolerizing capacity of $\mathrm{CDC} 1 \mathrm{~s}$ is not a property fully acquired at the time they undergo homeostatic maturation but needs to be enforced via MHCIl-restricted, suppressive interactions with regulatory T cells.

\section{INTRODUCTION}

Dendritic cells (DCs) can be subdivided into conventional type 1 (cDC1), conventional type 2 ( $\mathrm{cDC} 2)$, and plasmacytoid (pDC) DCs (1). cDC residing in steady-state tissues sample self-antigens (Ags) and undergo a terminal differentiation program-referred to as homeostatic maturation-enabling their migration to draining lymph nodes (LNs) and execution of tolerogenic function. It consists of continuously displaying self-Ags to induce anergy or to delete of strongly self-reactive $T$ cells that have escaped central tolerance and to maintain the suppressive function of Foxp $3^{+}$regulatory $\mathrm{T}\left(\mathrm{T}_{\text {reg }}\right)$ cells $(2,3)$. In contrast, when microbes breach tissue barriers, cDCs undergo immunogenic maturation, leading to the production of proinflammatory cytokines that relieve $\mathrm{T}_{\text {reg }}$ cell suppressive action and promote clonal expansion of effector T cells specific for microbial Ags.

cDC1s excel in loading exogenous Ags on major histocompatibility complex class I (MHCI) molecules, a process called Ag crosspresentation. It allows them to trigger $\mathrm{CD} 8^{+} \mathrm{T}$ cells specific for Ags in which they do not synthesize themselves including those of self- and foreign origins (4). K5.mOVA transgenic mice express a cell membranebound form of ovalbumin (OVA) in skin keratinocytes, the outer root sheath of the hair follicles, the esophagus epithelium, and medullary thymic epithelial cells (5). They have been used to study the mechanisms leading to the tolerization of adoptively transferred OT-I CD8 ${ }^{+} \mathrm{T}$ cells, the $\mathrm{T}$ cell receptor (TCR) of which has a high affinity for an OVA-derived peptide presented by $\mathrm{H}-2 \mathrm{~K}^{\mathrm{b}}$ MHCI molecules. After migration into draining cutaneous LNs (CLNs), dermal cDC1s were solely capable of cross-presenting keratinocyte-derived OVA to OT-I T cells $(6,7)$. As a result, OT-I T cells underwent an initial proliferation burst that was followed by their deletion over a period of 6 weeks $(5,8)$.

${ }^{1}$ Centre d'Immunologie de Marseille-Luminy, Aix Marseille Université, INSERM, CNRS, 13288 Marseille, France. ${ }^{2}$ Centre d'Immunophénomique, Aix Marseille Université, INSERM, CNRS, 13288 Marseille, France.

*Corresponding author. Email: bernardm@ciml.univ-mrs.fr (B.M.); henri@ciml.univ-mrs. fr (S.H.)

†These authors contributed equally to this work.
The Cre-loxP system has been extensively used for conditional gene knockout in cell types of interest. cDC1s can be identified across tissues by expression of the XC chemokine receptor 1 (XCR1) that binds to a single chemokine known as XCL1 (1, 9-11). Accordingly, we developed a mouse model in which a Cre recombinase and a fluorescent reporter were coexpressed under the control of the Xcr 1 gene, in a manner that maintains XCR 1 expression and preserves the XCL1-mediated cross-talk that occurs between natural killer (NK) cells, $\mathrm{pDCs}, \mathrm{CD}^{+}$memory $\mathrm{T}$ cells, and $\mathrm{cDC} 1 \mathrm{~s}$ (11-14). It differs from a former model in which a Cre recombinase replaced the entire coding sequence of the Xcrl gene (15). We exploited this model to generate mice that are specifically lacking MHCII molecules on $\mathrm{CDC} 1 \mathrm{~s}$ and evaluated whether they remained capable of cross-tolerizing $\mathrm{CD}^{+} \mathrm{T}$ cells that weakly or strongly react to self-Ags.

\section{RESULTS}

\section{A mouse model permitting specific gene ablation in CDC1s} does not affect XCR1 expression

To evaluate the role of candidate genes in $\mathrm{CDC} 1$ physiology, we generated gene-edited mice called $X c r 1^{\text {Cre-mTFP1 }}$ and containing in the $3^{\prime}$ untranslated region of their Xcrl gene an internal ribosomal entry site (IRES)-driven cassette comprising a codon-improved Cre recombinase (iCre) and a bright version of the monomeric teal fluorescent protein 1(mTFP1) cyan fluorescent reporter protein (see Materials and Methods). The resulting gene modification had no effect on $\mathrm{XCR} 1$ expression at $\mathrm{CDC} 1$ surface (fig. $\mathrm{S} 1 \mathrm{~A}$ ), and $\mathrm{CDCs}$ isolated from $X c r 1^{\text {Cre-mTFP1 }}$ mice coincidently expressed XCR1 and mTFP1 (fig. S1B). To demonstrate that Cre activity was restricted to $\mathrm{CDC1s}$, we crossed $\mathrm{X} c r 1^{\mathrm{Cre}-\mathrm{mTFP} 1}$ mice to Rosa2 $6^{\mathrm{LSL}-\mathrm{tdRFP}}$ mice in which Cre-mediated excision of a loxP-flanked transcriptional STOP element triggers expression of a red fluorescent protein (RFP). Analysis of DC subsets in the spleen, CLN, and skin of the resulting $X \mathrm{Cr}{ }^{\mathrm{RFP}}$ mice showed that all $\mathrm{CDC} 1 \mathrm{~s}$ were $\mathrm{RFP}^{+}$, regardless of their anatomical location and expression of $\mathrm{CD} 8 \alpha$, whereas $\mathrm{CDC} 2 \mathrm{~s}$ and Langerhans cells (LCs) expressed little $(<2 \%)$ or no detectable RFP, respectively (fig. S1, C to G). As 
expected, splenic B cells $\left(\mathrm{CD} 19^{+} \mathrm{CD} 45 \mathrm{R}^{+}\right), \mathrm{CD}^{+} \mathrm{T}$ cells $\left(\mathrm{CD}^{+} \mathrm{CD} 8^{+}\right)$, NK cells $\left(\mathrm{CD} 11 \mathrm{~b}^{\mathrm{int}} \mathrm{NK} 1.1^{+}\right)$, neutrophils $\left(\mathrm{CD} 11 \mathrm{~b}^{+} \mathrm{Ly}-6 \mathrm{G}^{+}\right)$, and pDCs $\left(\mathrm{CD} 45 \mathrm{R}^{+} \mathrm{PDCA}-1^{+}\right.$) were $\mathrm{RFP}^{-}$(fig. S1H). Unexpectedly, a small fraction $(<1 \%)$ of $\mathrm{CD}^{+} \mathrm{T}$ cells from the spleen of $\mathrm{Xcr}^{\mathrm{RFP}}$ mice expressed RFP (fig. S1, H and I). However, they did not express the XCR1 protein at their surface (fig. S1J), suggesting that Xcr1-driven Cre was transiently expressed in their progenitors. Unwanted germline deletion often occurs in Cre/loxP-based mouse models, the magnitude of which depends on floxed alleles (16). Analysis of mice resulting from inter- or backcrosses of $X c r 1^{\mathrm{RFP}}$ mice revealed that the $X c r 1^{\text {Cre-mTFP1 }}$ allele can sporadically delete the Rosa $26^{\text {dsl-tdRFP }}$ allele in the germ line, resulting in ubiquitous RFP expression. Accordingly, blood cells from $\mathrm{Xcr}^{\mathrm{RFP}}$ mice were systematically analyzed for adventitious RFP expression (see Materials and Methods), and mice with germline deletion were excluded from further study. Therefore, $X c r 1^{\text {Cre-mTFP1 }}$ mice permit specific gene ablation in $\mathrm{cDC} 1 \mathrm{~s}$ without affecting XCR1 expression.

\section{Absence of MHCIl on CDC1 triggers increased CD40 expression on $\mathrm{CDC1}$}

To generate mice with a cDC1-specific ablation of MHCII molecules $\left(X c r 1^{\mathrm{Ab} 1}\right.$ mice), we crossed $\mathrm{Xcr} 1^{\mathrm{Cre}-\mathrm{mTFP} 1}$ mice to mice expressing a loxP-flanked $H-2 I a^{b}$ allele (17). Consistent with a recent report (18) and our previous analysis of $X c r 1^{\mathrm{RFP}}$ mice, a high frequency of $X c r 1^{\mathrm{Abl}}$ mice were found to have deleted the $H-2 I a^{b}$ allele in a promiscuous manner outside of $\mathrm{CDC} 1 \mathrm{~s}$ and excluded from further study (see Materials and Methods). Analysis of DC subsets, $B$ cells, and neutrophils found in the peripheral lymphoid (spleen and CLN) and nonlymphoid (intestine, skin, and lung) tissues of the properly deleted $X c r 1^{\mathrm{Ab} 1}$ mice showed that MHCII molecule expression was retained on $B$ cells and $\mathrm{CDC} 2 \mathrm{~s}$ found in the spleen (Fig. 1A), intestine (Fig. 2B), skin (including LC; Fig. 2G), CLN (fig. S3A), and lung (including alveolar macrophages; fig. S3G). In contrast, MHCII molecule expression was lost on cDC1s across all tested organs of $\mathrm{Xcr} 1^{\mathrm{Abl}}$ mice (Figs. $1 \mathrm{~A}$ and $2, \mathrm{~B}$ and $\mathrm{G}$, and fig. $\mathrm{S} 3, \mathrm{~A}$ and $\mathrm{G}$ ). $X c r 1^{\mathrm{Ab} 1}$ mice followed for up to 52 weeks showed no weight loss (Fig. 2A) or neutrophilia (Figs. 1B and 2, $\mathrm{C}$ and $\mathrm{H}$, and fig. $\mathrm{S} 3, \mathrm{~B}$ and $\mathrm{H}$ ) and no sign of inflammation or pathological changes in the skin or intestine (Fig. 2, F and K). cDC1s undergo homeostatic maturation and can therefore be divided into CCR7 ("immature") and CCR7 ${ }^{+}$("mature") cells. In $\mathrm{Xcr}^{\mathrm{Ab} 1}$ mice, the numbers of splenic CCR7 ${ }^{+} \mathrm{cDC} 1 \mathrm{~s}$ and of immature and mature $\mathrm{CDC} 2 \mathrm{~s}$ remained unaffected, whereas a slight reduction was noted in splenic CCR7 ${ }^{-} \mathrm{cDC} 1$ s number (Fig. 1B). Absence of MHCII expression by $\mathrm{cDC} 1$ was also without impact on the absolute numbers of $\mathrm{cDC} 1 \mathrm{~s}$ and $\mathrm{cDC} 2 \mathrm{~s}$ found in the intestine (Fig. 2C), skin (Fig. 2H), CLN (fig. S3B), and lung (fig. S3H). cDC1 from the spleen (Fig. 1C and fig. S2A), intestine (Fig. 2D and fig. S2B), skin (Fig. 2I and fig. S2B), CLN (figs. S2C and S3C), and lung (fig. S2C and S3I) of $X \mathrm{Cr}^{\mathrm{Abl}}$ mice expressed increased surface levels of CD40 as compared with control (CTRL) mice. In contrast, cDC2s, which remained $\mathrm{MHCII}^{+}$in $\mathrm{Xcrl}^{\mathrm{Abl} 1}$ mice, expressed normal levels of CD40. Therefore, under steady-state conditions, specific deletion of MHCII molecules on cDC1s did not impair their homeostatic maturation and only led to increased CD40 expression.

\section{Absence of $\mathrm{MHCll}$ on $\mathrm{CDC1}$ results in higher numbers of effector memory $\mathrm{CD}^{+} \mathrm{T}$ cells}

The spleen of $X c r 1^{\mathrm{Ab} 1}$ mice showed normal percentages of conventional $\mathrm{CD}^{+} \mathrm{T}$ cells with a naïve to effector memory ratio compara- ble with that of CTRL mice (Fig. 1D). Unchanged percentages of natural $\left(\mathrm{Nrpl}^{+}\right)$and peripherally induced $\left(\mathrm{Nrpl}^{-}\right) \mathrm{T}_{\text {reg }}$ cells were also present in the spleen (Fig. 1E) of $X c r 1^{\mathrm{Abl}}$ mice. In addition, $\mathrm{T}_{\text {reg }}$ cells from $X c r 1^{\mathrm{Ab} 1}$ mice were as effective as those from CTRL mice in suppressing proliferation of conventional $\mathrm{CD}^{+} \mathrm{T}$ cells (Fig. 1F). The sole feature specific to T cells from $\mathrm{Xcrl}^{\mathrm{Ab} 1}$ mice was an increase in $\mathrm{CD} 62 \mathrm{~L}^{-} \mathrm{CD} 44^{+}$and in programmed cell death protein 1-positive $\left(\mathrm{PD}-1^{+}\right)$effector memory $\mathrm{CD} 8^{+} \mathrm{T}$ cells in the spleen (Fig. 1, G and H), CLN (fig. S3, E and F), intestine (Fig. 2E), skin (Fig. 2J), and lung (fig. S3J). Therefore, under steady-state conditions, specific deletion of MHCII molecules on cDC1s led to a significant increase in $\mathrm{CD} 8^{+} \mathrm{T}$ cells with an effector memory phenotype but was without measurable impact on the composition of the $\mathrm{CD} 4^{+} \mathrm{T}$ cell compartment.

\section{MHCII-deficient CDC1s show enhanced cross-presentation of a self-Ag expressed in keratinocytes}

To demonstrate the importance of $\mathrm{cDC} 1 \mathrm{~s}$ for cross-tolerizing strongly autoreactive OT-I T cells, we first crossed $X c r 1^{\text {Cre-mTFP1 }}$ mice to Rosa $26^{\text {lsl-DTA }}$ mice in which Cre-mediated excision of a loxP-flanked transcriptional STOP element triggers expression of diphtheria toxin fragment A (DTA) and results in the constitutive ablation of cDC1s (fig. S4). The resulting $X c r 1^{\text {DTA }}$ mice were further crossed to K5. mOVA mice to obtain K5.mOVA Xcr ${ }^{\text {DTA }}$ mice. Whereas adoptively transferred OT-I T cells proliferated in the CLNs of K5.mOVA CTRL mice (Fig. 3A), their proliferation was almost fully abrogated in K5.mOVA Xcrl ${ }^{\text {DTA }}$ mice (Fig. 3A), confirming that cross-presentation of keratinocyte-expressed OVA primarily depends on dermal migratory cDC1s (7).

Considering that $\mathrm{T}_{\text {reg }}$ cells exert a TCR-MHCII-dependent brake on steady-state CDCs $(19,20)$, we sought to determine whether lifting this brake via MHCII ablation enhanced the capacity of OVA-laden cDC1s to activate OT-I T cells. Adoptive transfer of OT-I T cells into K5.mOVA Xcr $1^{\mathrm{Ab} 1}$ mice led to elevated numbers of proliferating OT-I T cells in the CLNs as compared with transfer into K5.mOVA mice (Fig. 3B). Moreover, upon transfer into K5.mOVA Xcr ${ }^{\mathrm{Abl} 1}$ mice, OT-I T cells achieved a higher number of cell divisions (Fig. 3C) and showed increased percentage of interferon- $\gamma($ IFN- $\gamma$ )-producing cells (Fig. 3D) as compared with transfer into K5.mOVA mice. Therefore, absence of MHCII molecules on CDC1s enhanced their cross-priming capacity toward a self-Ag and increased Ag-induced production of IFN- $\gamma$ by autoreactive $\mathrm{CD} 8^{+} \mathrm{T}$ cells.

\section{Absence of MHCII molecules on CDC1s leads to an early-onset lethal autoimmunity toward a self-Ag expressed in keratinocytes}

In view of the exacerbated OT-I T cell activation resulting from OVA cross-presentation by MHCII-deficient $\mathrm{CDC1s}$, we tested next whether autoimmunity ensues in K5.mOVA Xcr ${ }^{\mathrm{Ab} 1}$ mice as compared with K5.mOVA mice. All the K5.mOVA Xcr ${ }^{\mathrm{Ab} 1}$ mice that had received OT-I T cells showed a rapid decrease in survival (Fig. 4A), associated with marked weight loss (Fig. 4B) and skin lesions (Fig. 4D) as compared with K5.mOVA CTRL mice. The severe weight loss manifested by K5.mOVA $X c r 1^{\mathrm{Ab} 1}$ mice as early as day 8 after OT-I T cell transfer was likely due to the expression of OVA in the esophagus epithelium of K5.mOVA mice (5), triggering marked esophageal lesions (Fig. 4C) and, in turn, impaired feeding. Eight days after adoptive transfer, OT-I T cells were 25 times more numerous in the CLNs of K5.mOVA Xcr ${ }^{\mathrm{Ab} 1}$ mice as compared 
A
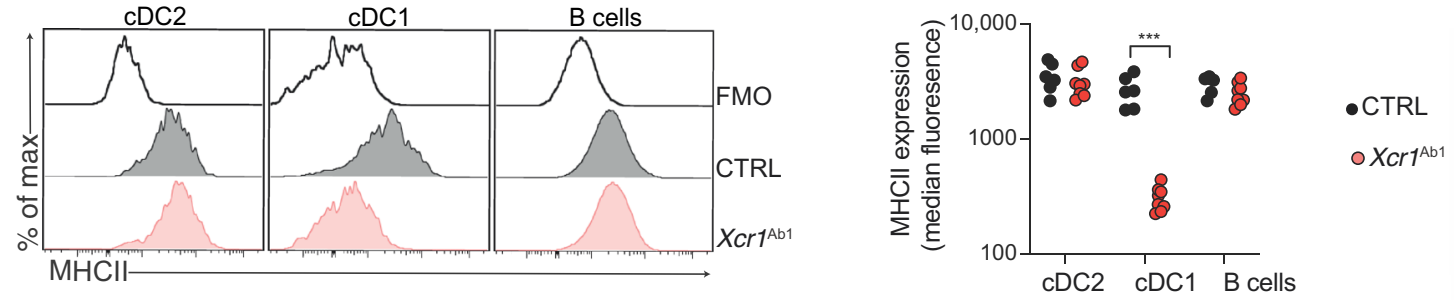

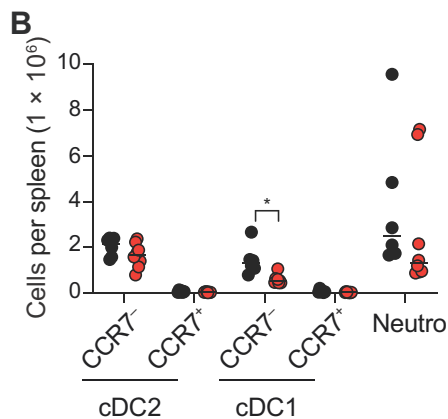

C

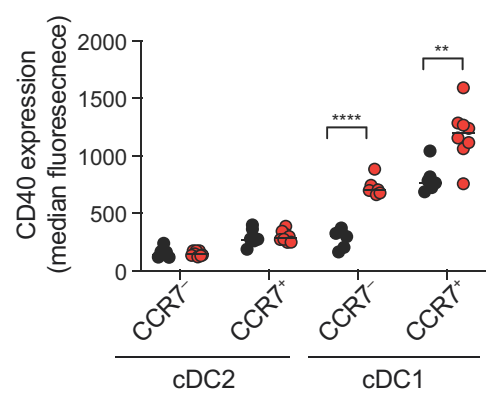

$\mathbf{F}$

E
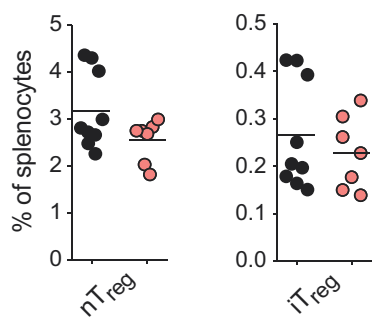

G

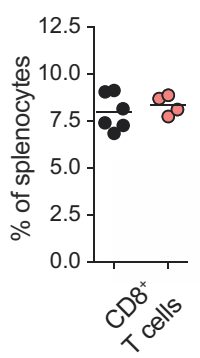

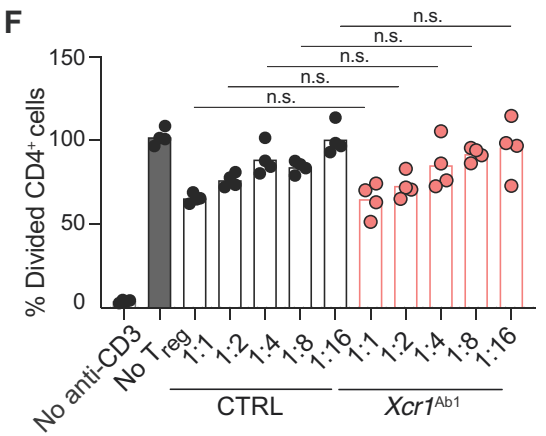

D

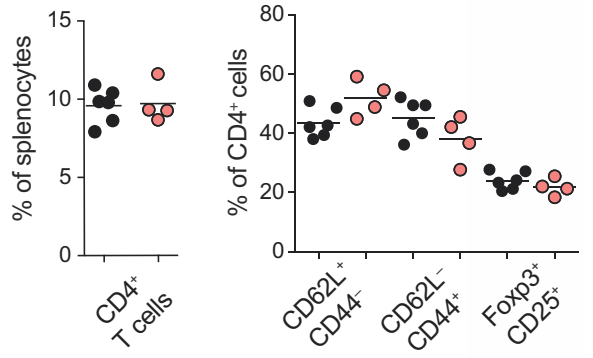

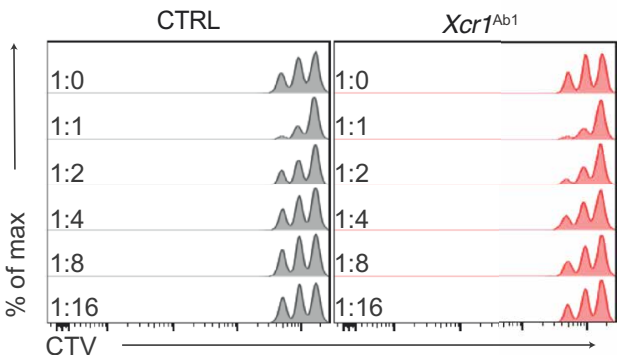

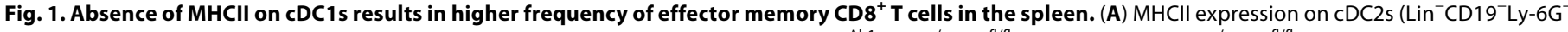

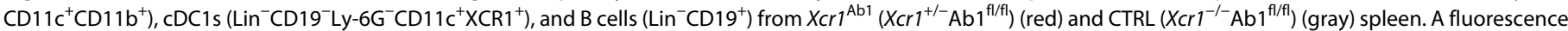
minus one (FMO) control without the anti-MHCIl antibody is shown. Median fluorescence levels of MHCIl molecules are also shown in the right. Data are representative of five experiments with $n \geq 4$ mice per group. (B) Absolute number of CCR7 ${ }^{-}$and CCR7 $7^{+}$cells among CDC2s and CDC1s and of neutrophils in the spleen of $X c r 1^{\mathrm{Ab} 1}$ and CTRL mice. Data are pooled from two independent experiments with $n \geq 3$ animals per group. (C) Median fluorescence levels of CD40 on CCR7 ${ }^{-}$and CCR7 ${ }^{+} \mathrm{CDC} 2 \mathrm{~s}$ and $\mathrm{CDC} 1 \mathrm{~s}$ found in the spleen of $X \mathrm{Cr} 1^{\mathrm{Ab} 1}$ and CTRL mice. Gating strategy for spleen B cells, CCR7 ${ }^{-}$and CCR7 ${ }^{+} \mathrm{CDC1s}$ and CDC2s, and neutrophils is shown in fig. S2A. (D) Percentage of $\mathrm{CD} 4^{+} \mathrm{T}$ cells among total splenocytes and of $\mathrm{CD}_{2} \mathrm{~L}^{+} \mathrm{CD} 44^{-}, \mathrm{CD} 2 \mathrm{~L}^{-} \mathrm{CD} 44^{+}$, and FoxP3 ${ }^{+} \mathrm{CD} 25^{+}$subsets among splenic $\mathrm{CD} 4^{+} \mathrm{T}$ cells of the specified mice. (E) Frequency of natural $\left(\mathrm{Nrp}^{+}{ }^{+} \mathrm{FoxP}^{+}\right)$and peripherally induced $\left(\mathrm{Nrp1}^{-}{ }^{-} \mathrm{FoxP3}^{+}\right) \mathrm{T}_{\text {reg }}$ cells among splenocytes of the specified mice. (F) $\mathrm{T}_{\text {reg }}$ cells from $\mathrm{CTRL}$ or $X \mathrm{Cr}{ }^{\mathrm{Ab} 1}$ mice were cultured at the indicated ratio with CTV-labeled conventional $\mathrm{CD}^{+} \mathrm{T}$ cells from CTRL mice in the presence of anti-CD3, and the percentage of conventional CD4 ${ }^{+} \mathrm{T}$ cells that have divided was evaluated after 60 hours of culture. n.s., not significant. (G) Percentage of CD8 ${ }^{+} T$ cells among total splenocytes and of CD62 ${ }^{+} C D 44^{-}, C^{2} 62 L^{+} C D 44^{+}$, and $\mathrm{CD} 62 \mathrm{~L}^{-} \mathrm{CD} 44^{+}$subsets among splenic CD8 ${ }^{+} \mathrm{T}$ cells. The absolute number of $\mathrm{CD} 62 \mathrm{~L}^{-} \mathrm{CD} 44^{+} \mathrm{CD} 8^{+} \mathrm{T}$ cells in $X \mathrm{Cr} 1^{\mathrm{Ab} 1}$ and $\mathrm{CTRL}$ mice is also shown. (H) PD- 1 and CD44 expression on $C D 8^{+} T$ cells from $X c r 1^{A b 1}$ and CTRL spleen. Also shown is the percentage of CD44 ${ }^{+} P D-1^{+} C D 8^{+} T$ cells. In (D), (E), (G), and (H), data are representative of three experiments with $n \geq 3$ mice per group. (F) Each dot corresponds to a single measurement and the corresponding mean (horizontal bar) is indicated; data are representative of two experiments. Samples were analyzed with one-way ANOVA with Sidak correction for multiple testing. In $(A)$ to $(E)$, $(G)$, and $(H)$, each dot corresponds to a mouse and the means (horizontal bar) are indicated, and samples were compared using two-tailed Student's $t$ test with Welch's correction. ${ }^{*} P<0.05,{ }^{* *} P<0.01,{ }^{* * *} P<0.001$. 
Fig. 2. The higher levels of CD40 expression on CDC1s and higher infiltrate of effector memory $\mathrm{CD8}^{+}$ $T$ cells in the gut and skin of $X c r 1^{\mathrm{Ab} 1}$ mice are not associated with inflammation. (A) Body weight of 52 weeks old $X \mathrm{Cr} 7^{\mathrm{Ab} 1}$ and CTRL littermates. (B) MHCII expression on CDC2s (Ly$6 \mathrm{G}^{-} \mathrm{CD} 19^{-} \mathrm{CD} 24^{-} \mathrm{CD} 11 \mathrm{~b}^{+}$ Ly-6 $\mathrm{C}^{-} \mathrm{CD} 64^{-}$) and $\mathrm{CDC1s}$ (Ly-6G ${ }^{-}$CD 19- CD24 $4^{+} \mathrm{CD} 11 b^{-}$ $\mathrm{XCR} 1^{+} \mathrm{CD} 11 \mathrm{c}^{+}$) from the gut of $\mathrm{Xcr}^{\mathrm{Ab} 1}\left(\mathrm{Xcr}^{+/-} \mathrm{Ab}^{\mathrm{fl} / \mathrm{fl}}\right)$ (red) and CTRL $\left(X_{C r}{ }^{-1-} A b 1^{f / / f}\right)$ (gray) littermates. Median fluorescence levels of MHCII molecules are also shown in the right. Data are representative of three experiments with $n \geq 3$ mice per group. (C) Absolute number of $C D C 2 s, C D C 1 s$, and neutrophils found in the gut of $\mathrm{XCr}^{\mathrm{Ab} 1}$ and CTRL littermates. (D) CD40 median fluorescence levels on $\mathrm{CDC} 2 \mathrm{~s}$ and $C D C 1 s$ found in the gut of $X_{C r} 1^{\mathrm{Ab} 1}$ and CTRL mice. (E) $\mathrm{CD}^{+} \mathrm{CD} 8^{+}$contour plots and absolute numbers of $\mathrm{CD}^{+} \mathrm{T}$ cells in the gut of $\mathrm{XCr}{ }^{\mathrm{Ab} 1}$ and CTRL mice. Gated $\mathrm{CD} 8{ }^{+} \mathrm{T}$ cells were analyzed for PD-1 and CD44 expression. Absolute numbers of $\mathrm{PD} 1{ }^{+} \mathrm{CD} 8^{+} \mathrm{T}$ cells in the gut of $X \mathrm{Cr} 1^{\mathrm{Ab} 1}$ and CTRL mice are shown in the right. (F) Representative H\&E-stained section of the small intestine of $\mathrm{CTRL}$ and $X \mathrm{Cr} 1^{\mathrm{Ab} 1}$ mice (objective, 20x). Scale bars, $50 \mu \mathrm{m}$. (G) MHCll expression on CDC2s (Ly-6G ${ }^{-} \mathrm{CD} 24^{-}$ CD11 b ${ }^{+}$Ly-6C CD64 ), CDC1s $\left(\right.$ Ly- $6 G^{-}$CD $24^{+}$CD $11 b^{\text {-tolow }}$ $X C R 1^{+} \mathrm{CD} 11 \mathrm{c}^{+}$), and LCs (Ly${ }_{6} \mathrm{G}^{-} \mathrm{CD} 24^{+} \mathrm{CD} 11 \mathrm{~b}^{\text {-tolow }} \mathrm{XCR} 1^{-}$ CD11 $\mathrm{c}^{+}$) from the skin of $\mathrm{XCr}^{\mathrm{Ab} 1}$ (red) and littermate

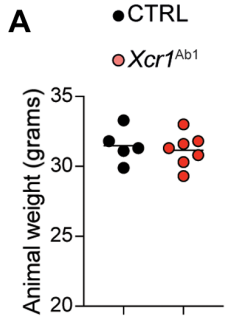

D

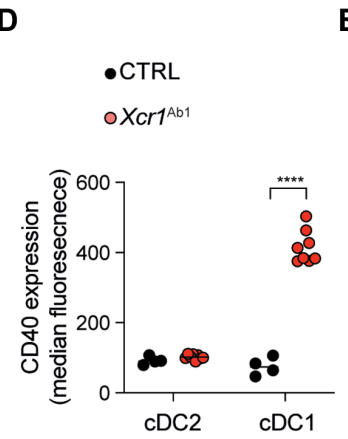

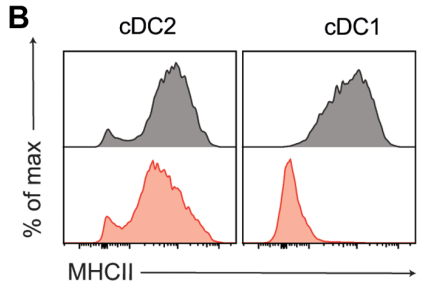

E

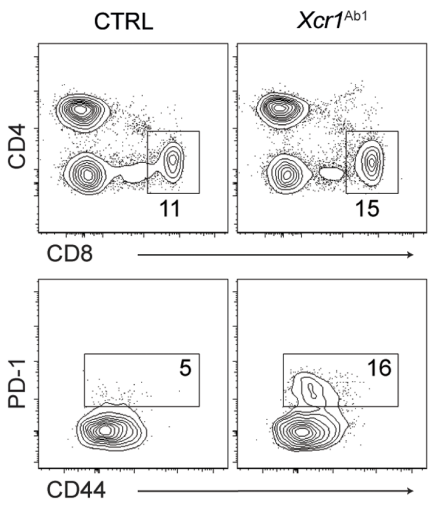

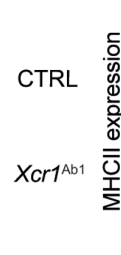

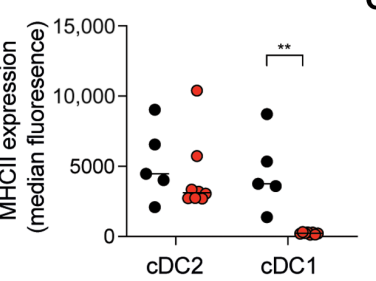

C

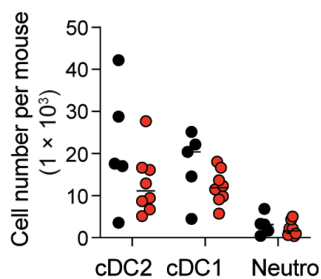

G

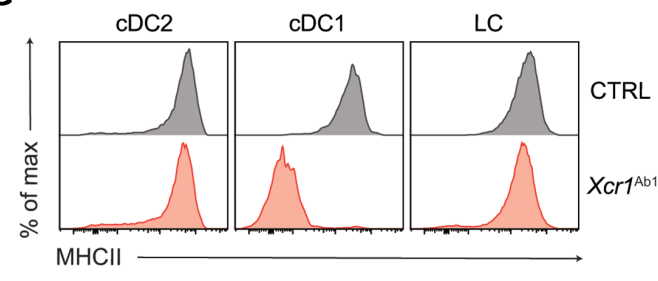

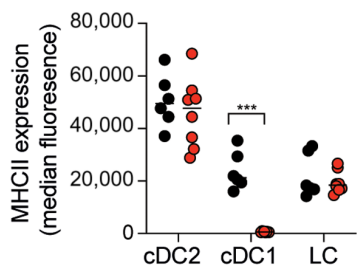

$\mathbf{F}$

CTRL

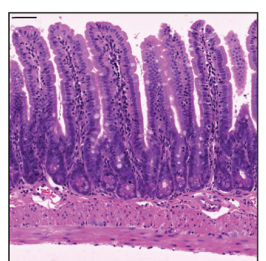

$X c r 1^{A b 1}$

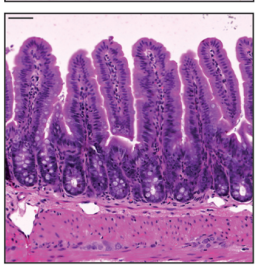

H

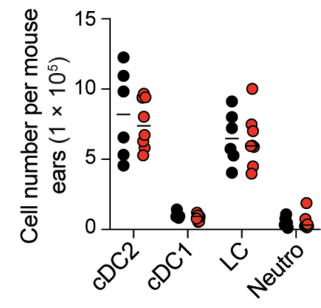

K

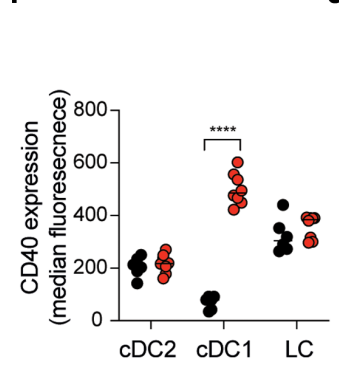

$\mathbf{J}$

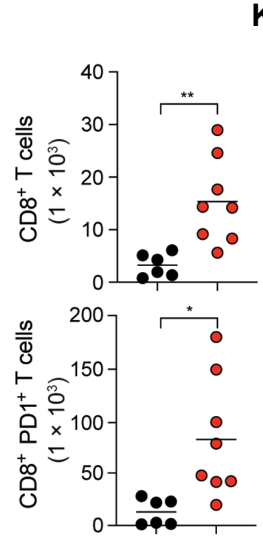

CTRL (gray) mice. Median fluorescence levels of MHCll molecules are also shown in the right. (H) Absolute numbers of $C D C 2 s, C D C 1 s, L C s$, and neutrophils found in the skin of $X \mathrm{Cr} 7^{\mathrm{Ab} 1}$ and CTRL littermates. (I) CD40 median fluorescence levels on $\mathrm{CDC} 2 \mathrm{~s}, \mathrm{CDC1s}$, and LCs found in the skin of $X \mathrm{Cr} \mathrm{1}^{\mathrm{Ab} 1}$ and CTRL mice. (J) CD4 $4^{+} \mathrm{CD} 8^{+}$contour plots and absolute numbers of $C D 8^{+} T$ cells in the skin of $X C r 1^{A b 1}$ and CTRL mice. Gated CD8 ${ }^{+} T$ cells were analyzed for PD- 1 and CD44 expression. Absolute numbers of $\mathrm{PD} 1^{+} \mathrm{CD} 8^{+} \mathrm{T}$ cells in the gut of $\mathrm{XCr}^{\mathrm{Ab} 1}$ and CTRL mice are shown in the right. (K) Representative H\&E-stained section of the back of the skin of CTRL and $X_{\mathrm{Cr}} 1^{\mathrm{Ab} 1}$ mice (objective, 20X). Scale bars, $100 \mu \mathrm{m}$. Gating strategies for CDC1s, CDC2s, neutrophils in the gut and skin and LC in the skin are detailed on fig. S2B. Each dot corresponds to a mouse and the means (horizontal bar) are indicated, and data are pooled from two independent experiments with $n \geq 3$ animals per group. Samples were compared using two-tailed Student's $t$ test with Welch's correction. ${ }^{*} P<0.05,{ }^{* *} P<0.01,{ }^{* * *} P<0.001,{ }^{* * * *} P<0.0001$.

with those of K5.mOVA mice (Fig. 4E). The CD44/CD62L profile of OT-I T cells found in the CLNs of K5.mOVA Xcr $1^{\mathrm{Ab} 1}$ and K5.mOVA mice corresponded to effector cells, and increased percentage of CD62 $\mathrm{L}^{-} \mathrm{CD} 44^{+} \mathrm{T}$ cells were found in K5.mOVA $X c r 1^{\mathrm{Abl}}$ CLN as compared with those of K5.mOVA mice (Fig. 4F). Consistent with the view that high expression of the $\mathrm{T}$ cell factor 1 
Fig. 3. MHCII-deficient CDC1s show enhanced cross-priming capacity toward a keratinocyteexpressed self-Ag. (A) CTV-labeled OT-I T cells $\left(1 \times 10^{6}\right)$ were transferred into CTRL, K5.mOVA, or K5.mOVA XCr ${ }^{\text {DTA }}$ hosts. CTV profiles and absolute numbers of proliferating CTV ${ }^{\text {low }}$ OT-IT cells found in the CLN 60 hours after transfer. In the plot shown in the right, each dot corresponds to a mouse and the means (horizontal bar) are indicated. Data are representative of three independent experiments with four mice per group. i.v., intravenously. (B) CTV profiles and absolute numbers of CTV low proliferating OT-I T cells in the $\mathrm{CLN}$ of $\mathrm{CTRL}, X_{\mathrm{Cr}}{ }^{\mathrm{Ab} 1}$, K5.mOVA, or K5.mOVA $X C r 1^{A b 1}$ mice 60 hours after adoptive transfer. (C) On the basis of the data shown in (B), the percentage of proliferating CTV ${ }^{\text {low }}$ OT-I T cells in each division cycle and the index of OT-I proliferation, replication, and expansion were calculated. (D) Production of IFN- $\gamma$ by CTV-labeled OT-I T cells isolated from K5.mOVA and K5.mOVA $X_{C r}{ }^{\mathrm{Ab} 1}$ mice 60 hours after adoptive transfer and after ex vivo restimulation. Also shown is the percentage of IFN- $\gamma^{+} \mathrm{CTV}^{\text {low }}$ OT-I T cells. (B to D) Each dot corresponds to a mouse and the means (horizontal bar) are indicated. Data are representative of three independent experiments with at least four mice per group. Samples were compared using two-tailed Student's $t$ test with Welch's correction. ${ }^{*} P<0.05,{ }^{* *} P<0.01$.

(TCF1) transcription factor counteracts the differentiation of effector $\mathrm{CD} 8^{+}$ $\mathrm{T}$ cells (21) and that the SLAM Family Member 6 (SLAMF6) surface receptor (also known as Ly108 or CD352) inhibits $\mathrm{T}$ cell responses (22), OT-I T cells found in K5.mOVA Xcr $1^{\mathrm{Ab} 1}$ CLN expressed diminished levels of both TCF1 (Fig. 4G) and SLAMF6 (Fig. 4H) as compared with their counterpart found in K5.mOVA mice. Moreover, histological analysis of the back skin of K5.mOVAXcr $1^{\mathrm{Ab} 1}$ mice 8 days after OT-I T cell transfer revealed severe epidermal erosion, perifollicular infiltration, and degeneration of the hair shafts, whereas no histopathological manifestations were observed in K5.mOVA mice that received the same numbers of OT-I T cells (Fig. 4I). Last, a significant increase $(P<0.05)$ of OT-I T cell was found in the skin of untreated $\mathrm{K} 5 . \mathrm{mOVA} \mathrm{Xcr1} 1^{\mathrm{Ab} 1}$ mice as compared with K5.mOVA CTRL mice (Fig. 4J). Therefore, the effector OT-I T cells elicited in the CLN of K5.mOVA Xcr $1^{\mathrm{Ab} 1}$ mice triggered a fatal early-onset autoimmunity resembling toxic epidermal necrolysis.

\section{Sequestration of autoreactive OT-I T cells in the CLN of K5. mOVA $X C r 1^{A b 1}$ mice rescues them from lethal autoimmunity} $T$ cell egress from LN requires the sphingosine- 1 phosphate receptor (S1PR), and the FTY-720 (fingolimod) immunosuppressant

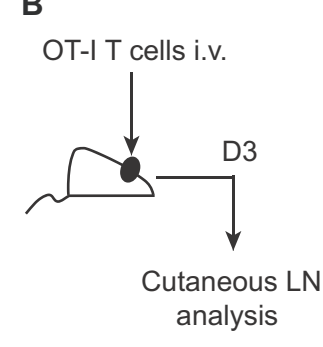

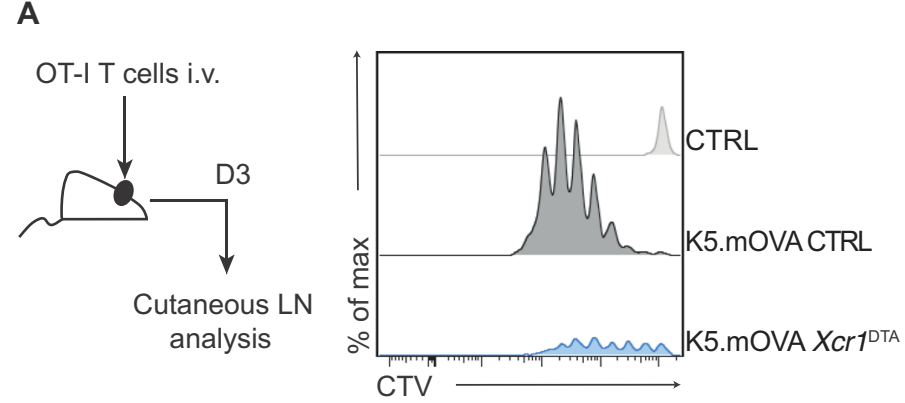
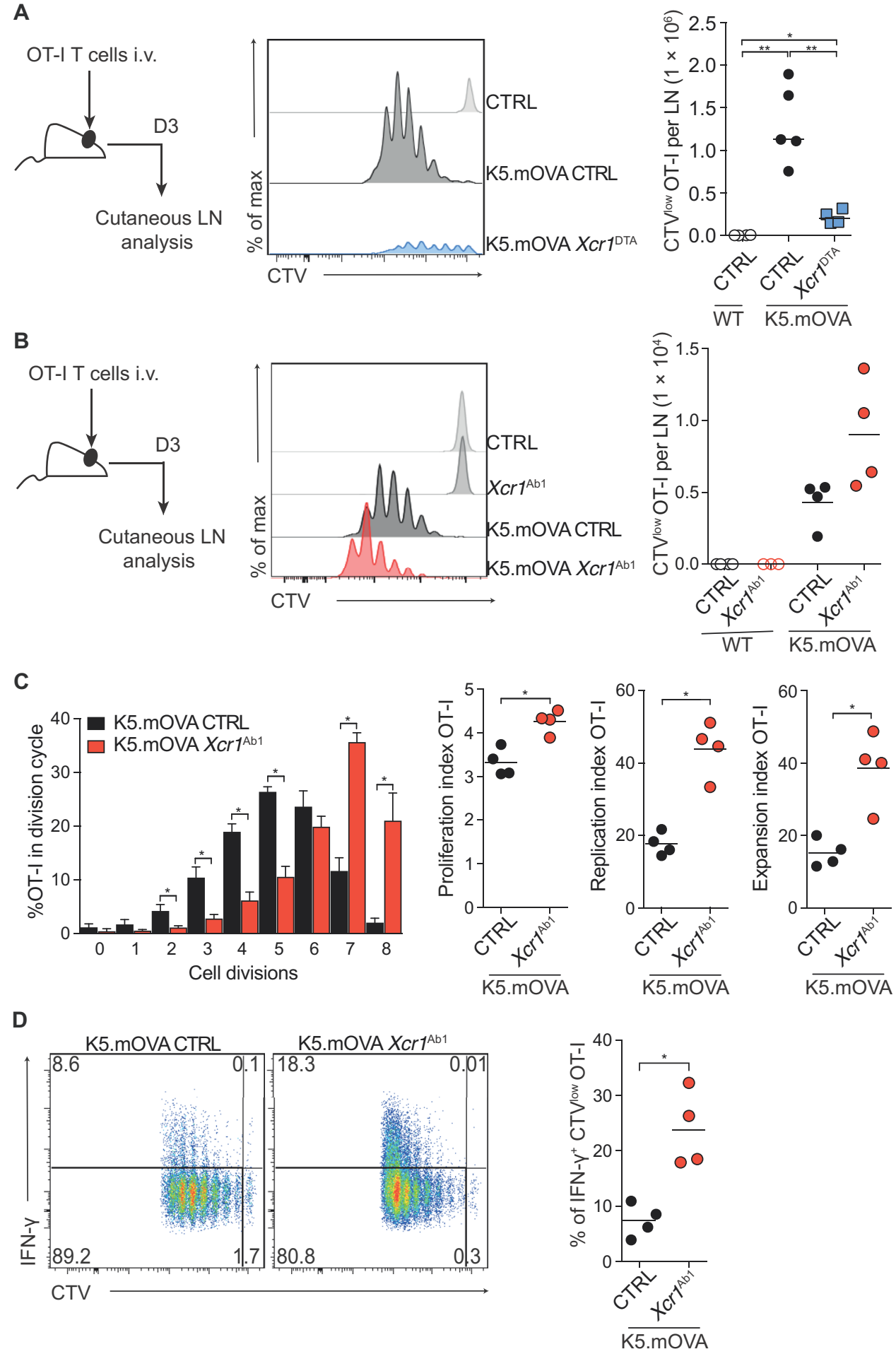

inhibits such emigration via down-regulation of S1PR (23). To establish a causal link between the activation of OT-I in the CLNs of K5.mOVA $X c r 1^{\mathrm{Ab} 1}$ mice and the occurrence of skin lesions, we adoptively transferred K5.mOVA Xcr ${ }^{\mathrm{Ab} 1}$ mice with OT-I T cells and then treated them with FTY-720 or left them untreated (Fig. 5A). The numbers of OT-I T cells expanding in the CLNs of FTY-720-treated K5.mOVA Xcr $1^{\mathrm{Ab} 1}$ mice were almost similar 
Fig. 4. Absence of MHCII molecules on CDC1s results in lethal autoimmune syndromes to keratinocyte-derived selfAg. (A) Experimental outline and percentage of diseasefree K5.mOVA CTRL (black line) and K5.mOVAX $\mathrm{Cr} 1^{\mathrm{Ab} 1}$ (red line) mice after adoptive transfer of OT-I T cells. Disease-free mice correspond to mice showing no weight loss and no sign of skin lesions. (B) Changes in body weight of $\mathrm{K} 5$. MOVA CTRL (blackline) and K5.mOVAX $\mathrm{Cr}^{\mathrm{Ab} 1}$ (red line) mice after OT-I T cell transfer. Each line corresponds to one individual mouse. (C) Representative H\&E-stained section of the esophagus of K5.mOVA CTRL and K5.mOVA $\mathrm{XCr} 1^{\mathrm{Ab} 1}$ mice that received OT-I T cells (objective, 20X; scale bars, $100 \mu \mathrm{m}$ ). (D) Macroscopic manifestations of the skin pathology developing in K5.mOVA $X \mathrm{Cr}^{\mathrm{Ab} 1}$ mice after OT-I T cell transfer as compared with K5.mOVA mice. In (B) to (E), data are representative of $n \geq 3$ independent experiments with $n \geq 3$ mice per group. (E) Absolute numbers of CTV ${ }^{\text {low }}$ proliferating OT-I T cells in the CLNs of the specified mice. (F) CD62L versus CD44 expression of proliferating OT-I T cells found in the CLNs of the specified mice and corresponding percentages of $\mathrm{CD}_{2} \mathrm{~L}^{+} \mathrm{CD} 44^{+}$and CD62L $\mathrm{L}^{-} \mathrm{CD} 44^{+}$ cells among proliferating OT-I T cells. (G)TCF1 expressionamong proliferating OT-IT cells from the CLNs of the specified mice. Also shown is the percentage of TCF1 ${ }^{-}$cells. (H) Ly108/SLAMF6 expression on proliferating OT-I T cells and percentage of Ly $108^{-}$cells among proliferating OT-I cells. (I) Representative $\mathrm{H \& E}$-stained sections of the back of the skin of K5.mOVA CTRL and K5.mOVA $X_{C r} 1^{\mathrm{Ab} 1}$ mice that received OT-I T cells (objective, 20x; scale bars, $100 \mu \mathrm{m})$. (J) Absolute numbers of skin-infiltrating OT-IT

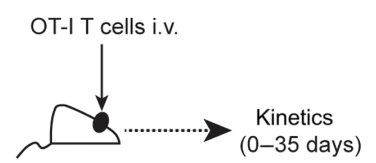

$\perp$ K5.mOVACTRL $(n=8)$

$\perp \mathrm{K} 5 . \mathrm{mOVAXCr}{ }^{\mathrm{Ab} 1}(n=6)$

B

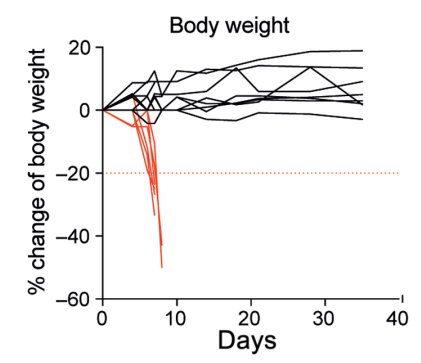

E

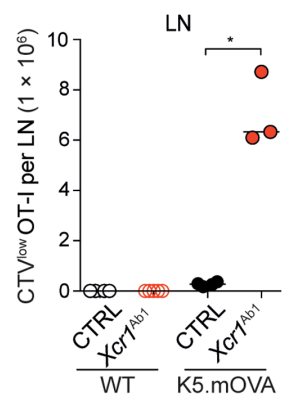

G

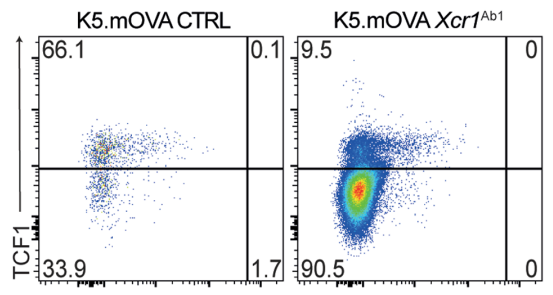

CTV

I

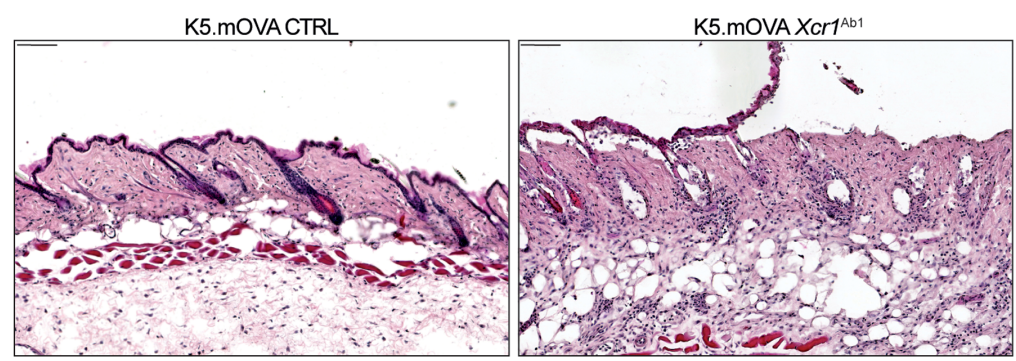

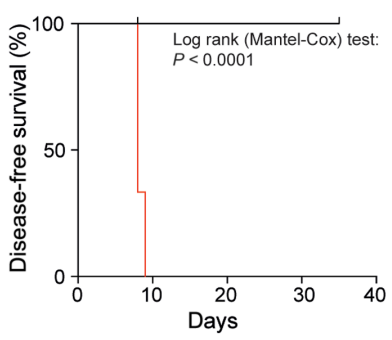

C

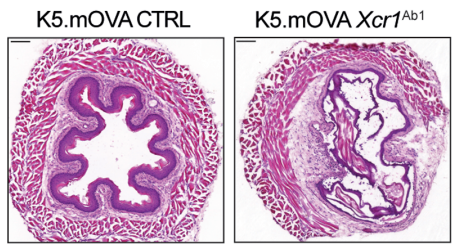

K5.mOVACTRL

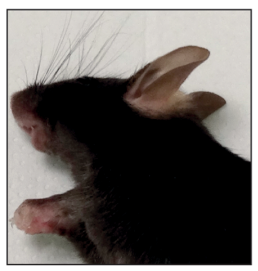

K5. mOVAX ${ }^{2} 1^{A b}$

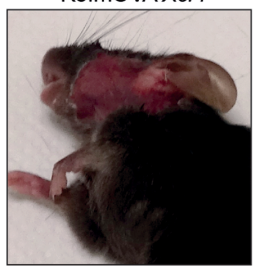
Data are representative of two independent experiments with $n \geq 3$ mice per group.

to those of K5.mOVA Xcr ${ }^{\mathrm{Ab} 1}$ mice (Fig. 5B). A large infiltrate of OT-I T cells was found in the skin of untreated K5.mOVA Xcr ${ }^{\mathrm{Abl}}$ mice as compared with K5.mOVA mice. It was associated with increased numbers of total $\mathrm{CD} 4{ }^{+} \mathrm{T}$ cells that included FoxP3 ${ }^{+} \mathrm{CD} 4^{+}$ $\mathrm{T}$ cells and a massive infiltrate of monocytes and neutrophils (Fig. 5, C and D). FTY-720 treatment markedly decreased the 
A

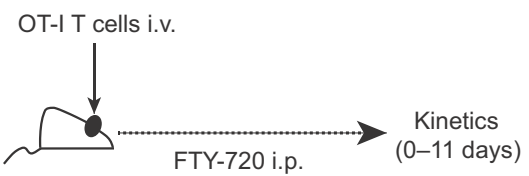

Days 2, 4, 6, 8, and 10
B

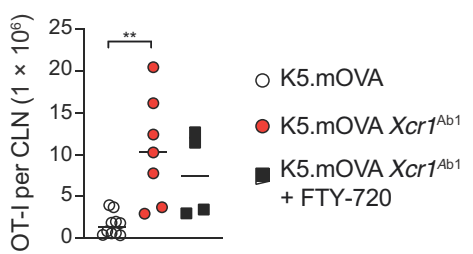

C

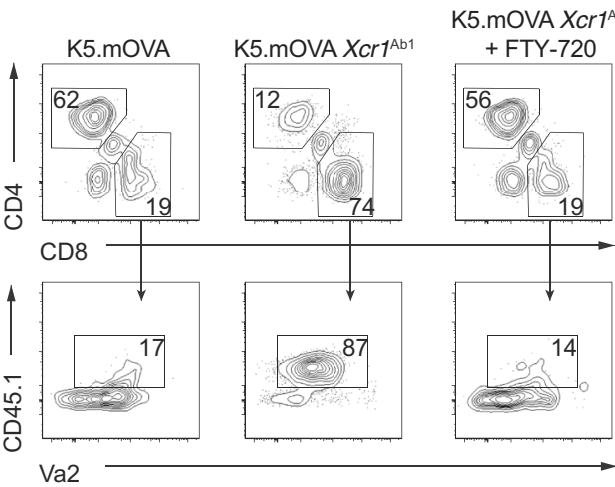

$\mathrm{IFN}-\gamma^{+}$
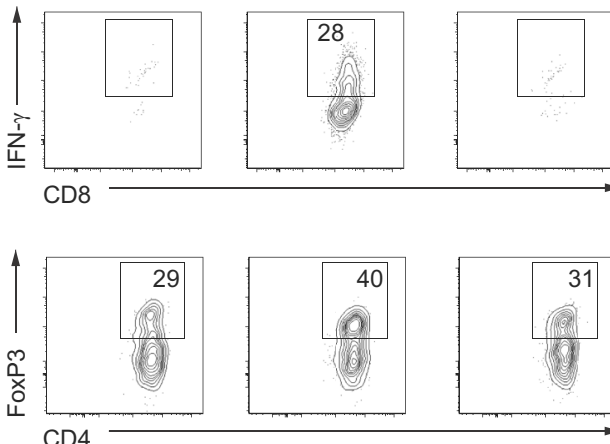
CD4
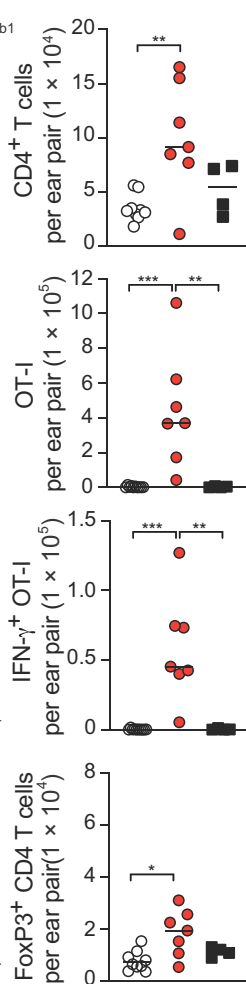

D
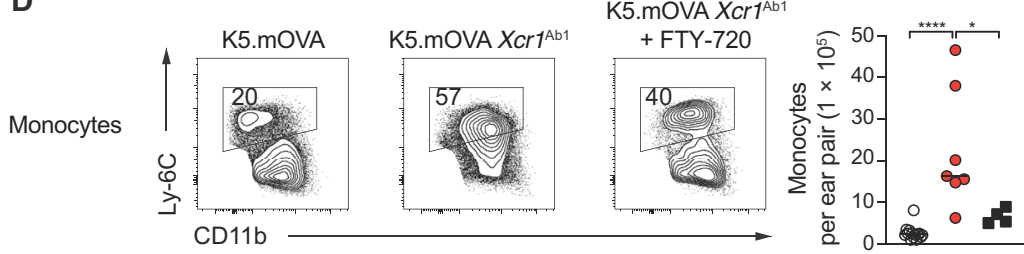

Neutrophils
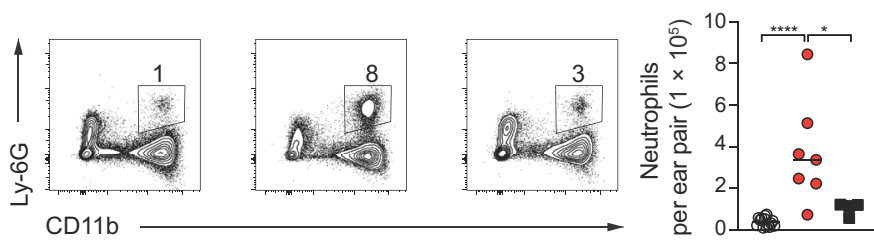

E

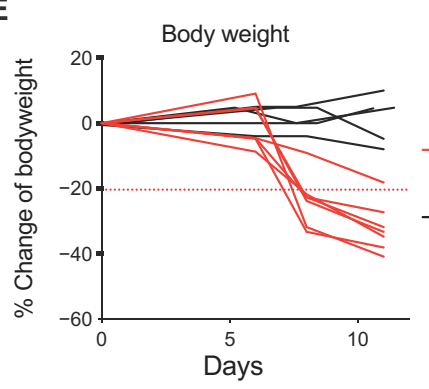

Fig. 5. Sequestering autoreactive OT-I T cells in the CLN of K5.mOVA $X c r 1^{\mathrm{Ab} 1}$ mice prevents unfolding of the lethal autoimmune syndrome. (A) Experimental outline. From day 2 postadoptive transfer of OT-IT cells, mice were treated with FTY-720 to impair T cell egress from the CLNs. i.p., intraperitoneally. (B) Absolute numbers of OT-I T cells ( $\mathrm{Lin}^{-} \mathrm{TCR} \beta^{+} \mathrm{CD} 3^{+} \mathrm{CD} 8^{+}$ $\left.\mathrm{V} \alpha 2^{+} \mathrm{CD} 45.1^{+}\right)$in the CLNs of the specified mice. (C) FACS plots and absolute numbers of $\mathrm{CD} 4^{+} \mathrm{T}$ cells $\left(\operatorname{Lin} \mathrm{TCR} \beta^{+} \mathrm{CD} 3^{+} \mathrm{CD} 4^{+}\right)$, OT-I T cells ( $\left.\mathrm{Lin}^{-} \mathrm{TCR} \beta^{+} \mathrm{CD}^{+} \mathrm{CD}^{+} \mathrm{V} \alpha 2^{+} \mathrm{CD} 45.1^{+}\right)$, and IFN- $\gamma^{+}$OT-I $T$ cells found in the ear skin of the specified mice. (D) FACS plots and absolute numbers of monocytes (Ly- $6 \mathrm{G}^{-} \mathrm{Lin}^{-} \mathrm{CD} 24^{-}$ CD $11 b^{+} \mathrm{Ly}^{-} 6 \mathrm{C}^{+} \mathrm{CD} 64^{\text {lowto+ }}$ ) and neutrophils ( $\left.\mathrm{Lin}^{-} \mathrm{CD} 11 \mathrm{~b}^{+} \mathrm{Ly}-6 \mathrm{G}^{+}\right)$in the ear skin of the specified mice. (E) Changes in body weight of FTY-720-untreated K5.mOVA $\mathrm{CCr}^{\mathrm{Ab} 1}$ (red line) and FTY-720treated $\mathrm{K} 5 . \mathrm{mOVAX} \mathrm{Xr1}^{\mathrm{Ab} 1}$ (black line) mice after OT-IT cell transfer. Each line corresponds to one individual mouse. (F) Presence of macroscopic skin lesions in K5.mOVA CTRL, FTY-720-untreated K5.mOVA $X_{C r} 1^{\mathrm{Ab} 1}$, and FTY-720-treated K5.mOVA $X_{C r}{ }^{\mathrm{Ab} 1}$ mice that received OT-I T cells. In (B) to (D), samples were compared using two-tailed Student's $t$ test with Welch's correction. ${ }^{*} P<0.05,{ }^{* *} P<0.01,{ }^{* * *} P<0.001,{ }^{* * *} P<0.0001$. Data are pooled from two independent experiments with $n \geq 2$ mice per group.

numbers of skin-infiltrating OT-I T cells, including those producing IFN- $\gamma, \mathrm{CD}^{+} \mathrm{T}$ cells, monocytes, and neutrophils as compared with untreated $\mathrm{K} 5$. mOVA $X c r 1^{\mathrm{Ab} 1}$ mice (Fig. 5, C and D). As a result, FTY-720-treated K5.mOVA Xcr $1^{\mathrm{Ab} 1}$ mice presented neither a marked weight loss (Fig. 5E) nor skin lesions (Fig. 5F) as compared with untreated K5.mOVA $X c r 1^{\mathrm{Ab} 1}$ mice. Therefore, the potent OT-I effector $\mathrm{T}$ cells that are induced in the draining $\mathrm{LN}$ of $\mathrm{K} 5$. mOVA $X c r 1^{\mathrm{Ab} 1}$ mice in response to OVA crosspresented by MHCII-deficient CDC1s account for the early-onset and fatal autoimmunity observed in those mice.

\section{DISCUSSION}

Original mouse models aiming at assessing the role of MHCII molecules in vivo led to their conditional deletion on B cells, DCs, macrophages, and thymic epithelial cells (24). A more recent study revealed that direct TCR-MHCII interactions between suppressive $\mathrm{CD} 4^{+} \mathrm{T}$ cells and $\mathrm{CD} 11 \mathrm{c}^{+}$cells were essential for induction of peripheral $\mathrm{CD}^{+} \mathrm{T}$ cell tolerance (19). Considering that the $\mathrm{MHCII}^{+} \mathrm{CD} 11 \mathrm{c}^{+}$cells comprised cDC2s, monocyte-derived DCs, macrophages, and pDC in addition to $\mathrm{CDCls}$, we generated mice in which $\mathrm{CDC1s}$ are specifically deprived of MHCII and analyzed whether they remained capable of tolerizing $\mathrm{CD} 8^{+} \mathrm{T}$ cells that were either weakly or strongly autoreactive.

Most of naïve $\mathrm{T}$ cells circulating in the periphery have been selected during thymic selection to be weakly autoreactive and continuously engage their TCR with self-peptide MHC complexes expressed by $\mathrm{cDCs}$ to maintain a state of heightened Ag sensitivity to foreign Ags (25-27). It has been argued that the need for such weak "tonic" TCR signals creates a potential threat that cannot be constrained by negative regulatory 
mechanisms intrinsic to conventional naïve $\mathrm{T}$ cells and that such risk is buffered by the suppressive action of $\mathrm{T}_{\text {reg }}$ cells $(28,29)$. Accordingly, after homeostatic maturation, cDCs serve as informationtransmission platform favoring the encounter of $\mathrm{T}_{\text {reg }}$ cells and naïve $\mathrm{T}$ cells (30). As a result, $\mathrm{T}_{\text {reg }}$ cells down-regulate the levels of CD80/ CD86 ligands available on cDCs via transendocytosis, thereby increasing the threshold above which TCR signals must rise to trigger a productive response in naïve $\mathrm{T}$ cells $(20,29,31,32) . \mathrm{T}_{\text {reg }}$ cells can also consume interleukin-2 (IL-2) to suppress activation of neighboring naïve $\mathrm{CD}^{+} \mathrm{T}$ cells and suppress naïve $\mathrm{CD} 4^{+} \mathrm{T}$ cells using pathways other than IL-2 consumption (28).

By depriving cDC1s of MHCII molecules and preventing them from receiving suppressive $T_{\text {reg }}$ cell inputs, the first objective of the present study was to determine whether $\mathrm{CDC} 1$ s lose their tolerogenicity and instead trigger the differentiation of the weakly self-reactive naïve $\mathrm{CD}^{+} \mathrm{T}$ cells that populate the periphery into effector cells capable of inducing autoimmunity. A twofold increase in the percentage of CD62 $\mathrm{L}^{-} \mathrm{CD} 44^{+} \mathrm{PD}-1^{+}$effector memory $\mathrm{CD}^{+} \mathrm{T}$ cells was noted in mice containing MHCII-deficient $\mathrm{CDC} 1 \mathrm{~s}$, which did not, however, result in inflammation or autoimmunity when mice were analyzed for up to 52 weeks. $\mathrm{T}_{\text {reg }}$ cells isolated from mice with MHCII-deficient cDC1s were as effective as $\mathrm{T}_{\text {reg }}$ cells isolated from CTRL mice in suppressing proliferation, suggesting that expression of MHCII on CDC2s sufficed to select and maintain normal numbers of $\mathrm{T}_{\text {reg }}$ cells with intact suppressive capacity. In support of that view, mice lacking MHCII on both $\mathrm{CDC} 1 \mathrm{~s}$ and $\mathrm{CDC} 2 \mathrm{~s}$ exhibited profound intestinal inflammation (33) and thus markedly differed from mice with MHCII-deficient cDC1s.

Peptide MHCI tetramer-based studies showed that central tolerance is much less complete than previously anticipated in that strongly autoreactive $\mathrm{CD} 8^{+} \mathrm{T}$ cells specific for the $\mathrm{Y}$ chromosome-encoded selected mouse cDNA on Y (SMCY) Ag are found in the periphery of male individuals. They showed a threefold lower frequency as compared with female individuals and had a TCR affinity distribution overlapping that of female individuals (34). Considering that such strongly autoreactive $\mathrm{CD} 8^{+} \mathrm{T}$ cells are likely under control of Ag-specific $\mathrm{T}_{\text {reg }}$ cells $(31,35)$, the second objective of the present work was to assess whether MHCII-deficient CDC1s maturing under homeostatic conditions were capable of tolerizing strongly autoreactive $\mathrm{CD} 8^{+} \mathrm{T}$ cells. In the case where mice specifically lack MHCII molecules on $\mathrm{CDC} 1 \mathrm{~s}$, $\mathrm{CD}^{+} \mathrm{T}$ cells with a strong affinity for self-Ag presented on both $\mathrm{CDC} 1 \mathrm{~s}$ and $\mathrm{CDC} 2 \mathrm{~s}$ will undergo both $\mathrm{CDC} 2$-mediated tolerizing encounters and $\mathrm{CDC} 1$-mediated nontolerizing encounters. On the basis of previous experiments using bone marrow chimeras (19), it can be surmised that tolerization will constitute the net result. In contrast, provided that $\mathrm{CDC} 1 \mathrm{~s}$ lack MHCII molecules and that the strongly autoreactive $\mathrm{CD}^{+} \mathrm{T}$ cells recognize self-Ag that are solely presented on cDC1s, only cDC1-mediated nontolerizing encounters will ensue, resulting in cytotoxic $\mathrm{T}$ lymphocyte-mediated autoimmunity. To model this last condition, we exploited the fact that the $\mathrm{CDC} 1 \mathrm{~s}$ found in K5.mOVA mice are the sole skin cDCs capable of cross-tolerizing strongly reactive OT-I CD ${ }^{+} \mathrm{T}$ cells toward keratinocyte-expressed $\operatorname{OVA}(6,7)$. Note that, in our model, the frequency of OT-I precursors achieved upon adoptive transfer overrides $\mathrm{CD} 4^{+} \mathrm{T}$ cell help $(36,37)$, making $\mathrm{cDC} 1$ s only sensitive to $\mathrm{T}_{\text {reg }}$ cell input. When K5.mOVA mice were adoptively transferred with OT-I T cells, their $\mathrm{MHCII}^{+} \mathrm{cDC1}$ were capable to cope with such frequency of strongly autoreactive T cell precursors in that their skin showed only transient microscopic lesions that contained apoptotic keratinocytes and resolved upon time (5). In contrast, MHCII-deficient $\mathrm{cDC} 1 \mathrm{~s}$ cross-primed OT-I T cells into effectors responsible for lethal autoimmunity. Supporting the view that it is the lack of $\mathrm{T}_{\text {reg }}$ cell inputs on OVA-laden, MHCII-deficient $\mathrm{cDC} 1 \mathrm{~s}$ that accounted for the ensuing fatal autoimmunity, the skin lesions observed in these animals closely resembled those of athymic K5.mOVA mice adoptively transferred with OT-I T cells in absence of $\mathrm{T}_{\text {reg }}$ cells (38).

In conclusion, we established that, under homeostatic conditions, tissue-resident $\mathrm{CDC} 1 \mathrm{~s}$ mature and migrate to draining $\mathrm{LN}$ irrespective of $\mathrm{CD} 4^{+} \mathrm{T}$ cell-cDC1 interactions. However, proper execution of their tolerogenic function in the draining $\mathrm{LN}$ requires $\mathrm{MHCII}$-restricted interactions with $\mathrm{T}_{\text {reg }}$ cells. The need for $\mathrm{T}_{\text {reg }}$ cell-cDC interaction was found particularly important for tolerizing the strongly autoreactive $\mathrm{CD}^{+} \mathrm{T}$ that escape thymic selection (34). Further studies will be necessary to test whether our observation extends to models other than the K5.mOVA OT-I model used in the present study. Therefore, consistent with recent studies $(9,39)$, cDC maturation should not be viewed as a binary "on-off" event but rather as an extended, multistep process that initiates in tissue parenchyma and continues in tissue-draining LN via the integration of extrinsic signals that are delivered by $\mathrm{T}_{\text {reg }}$ cells and $\mathrm{CD} 4^{+}$helper $\mathrm{T}$ cells (40) and determines the final capacity of a given DC to perform tolerogenic or immunogenic functions, respectively. Future studies should help to further define at the system levels, the transcriptional, translational, and posttranslational changes that occur in $\mathrm{CDC} 1 \mathrm{~s}$ as a result of their interaction with $\mathrm{T}_{\text {reg }}$ cells.

\section{MATERIALS AND METHODS Study design}

The objective of the present study was to determine whether preventing $\mathrm{cDC} 1 \mathrm{~s}$ to receive suppressive $\mathrm{T}_{\text {reg }}$ inputs abolishes their capacity of tolerizing autoreactive $\mathrm{CD}^{+}{ }^{+} \mathrm{T}$ cells. Accordingly, we developed a mouse model in which cDC1s specifically lacked MHCII and backcrossed it to K5.mOVA transgenic mice that express a cell membrane-bound form of OVA in skin keratinocytes. Experiments were designed to validate the model and gauge whether OVA-laden, MHCII-deficient cDC1s lose their capacity of cross-tolerizing adoptively transferred $\mathrm{CD}^{+} \mathrm{T}$ cells specific for OVA. The number of mice per experimental group and the number of repetitions of the experiments are indicated in the individual figure legends.

\section{Mice}

Generation of $X c r 1^{\text {Cre-mTFP1 }}$ mice is described below. $H 2-A b 1^{\mathrm{fl}}$ (B6.129X1-H2-Ab1 $\left.{ }^{\text {tm1Koni }} / \mathrm{J}\right)$, Rosa $26^{\text {LSL-DTA }}$ [B6.129P2-Gt (ROSA) 26Sor ${ }^{\text {tm1(DTA L L ky/J }], ~ R o s a 26 ~}{ }^{\text {LSL-tdRFP }}\left[G t(R O S A) 26^{\text {Sortm } 1 H i f}\right]$, and K5.mOVA mice were previously described $(5,17,41,42)$. All mice were maintained on C57BL/6 (B6) background. OT-I mice (43) were kept on a CD45.1/CD45.2 B6 background. CD45.1 B6 mice were from Charles River. Mice were housed under specific pathogen-free conditions, and in vivo procedures were performed following protocols approved by the Ethics Committee of Marseille in accordance with institutional, national, and European directives for animal care (approval APAFIS 779-2015 0605 10534083).

\section{Generation of Xcr1-IRES-iCre-GSG-2A-mTFP1 mice}

A targeting construct was designed to introduce an IRES-iCreGSG-2A-mTFP1 cassette in the $3^{\prime}$ untranslated region of the Xcr 1 gene, 29-base pair (bp) downstream of the stop codon. IRES corresponds to an IRES, iCre to a sequence coding for a iCre (44), 2A to 
the sequence coding for a self-cleaving $2 \mathrm{~A}$ peptide, and mTFP1 to a sequence coding for a monomeric, bright, and photostable version of Clavularia cyan fluorescent protein (45). JM8.F6 C57BL/6N embryonic stem (ES) cells (46) were electroporated with the targeting vector. After selection in G418, ES cell clones were screened for proper homologous recombination by polymerase chain reaction and Southern blot. Properly recombined ES cells were injected into FVB blastocysts. After germline transmission, excision of the frt-neo ${ }^{r}$-frt cassette was achieved through crossing with mice expressing an FLP recombinase (47). Two pairs of primers were used to distinguish the wild-type (WT) and edited Xcrl alleles. The first pair (sense, 5'-TCCTGAAAACTGGAATCATC-3'; antisense, 5' -TTTTCTTTCTGTAGCTGCTAAG-3') amplified a 635-bp band in case of the WT Xcr 1 allele, whereas the second pair (sense, $5^{\prime}$-TCTACGAGATACACCTCAAG-3'; antisense, 5'-TTTTCTTTCTGTAGCTGCTAAG-3') amplified a 775-bp band in the case of the Xcr1-IRES-iCre-GSG2A-mTFP1 allele.

\section{Detection of germline deletion in $X_{c r} 1^{\mathrm{RFP}}$ and $X_{\mathrm{Cr}} 1^{\mathrm{Ab} 1}$ mice} In both $X c r 1^{\mathrm{RFP}}$ and $X c r 1^{\mathrm{Ab} 1}$ models, mice with adventitious germline deletion were excluded from our study. Accordingly, flow cytometry analysis was used to check whether RFP was ubiquitously expressed in blood cells of Xcr ${ }^{\mathrm{RFP}}$ mice or whether MHCII molecules were lacking at the surface of B cells from the blood of $X c r 1^{\mathrm{Ab} 1}$ mice. Germline deletion in $X c r 1^{\mathrm{Ab} 1}$ mice was further tested by tail DNA genotyping using sense ( $5^{\prime}$-AAGCCAGGAAGGGACCAGAGCCTCT $-3^{\prime}$ ) and antisense (5'-TTGCCAGTTTCTGCTACCCCACCC- $3^{\prime}$ ) primers, allowing to detect a 4642-bp band and a 398-bp band corresponding loxP-flanked and floxed $H 2-A b 1^{\mathrm{fl}}$ alleles, respectively.

\section{Cell preparations and isolation from tissues}

Cells were isolated from the ear skin as described (48). Briefly, ears were incubated for $105 \mathrm{~min}$ at $37^{\circ} \mathrm{C}$ in RPMI 1640 containing Liberase TL (0.25 mg/ml; Roche Diagnostic Corp.) and deoxyribonuclease I (DNase I) $(0.5 \mathrm{mg} / \mathrm{ml}$; Sigma-Aldrich). Digested tissue was homogenized using Medicons and Medimachine (BD Biosciences). To isolate cells from the skin of the mouse back, the skin was digested in RPMI with Liberase TL and DNase and homogenized using C tube and gentleMACS Dissociator (Miltenyi Biotec). For isolation of cells from the spleen and LN, organs were cut into small pieces and digested for $25 \mathrm{~min}$ at $37^{\circ} \mathrm{C}$ with type II collagenase (Worthington Biochemical) and DNase I in 2\% fetal bovine serum (FBS) RPMI. Red blood cells of the spleen were lysed using the Red Blood Cell Lysis Buffer (eBioscience). For isolation of cells from the lamina propria of the large intestine, the intestinal tissue was opened longitudinally, cut into pieces, and washed in Hanks' balanced salt solution (HBSS). The epithelial cell layer was isolated by two consecutive incubations of 20 and $30 \mathrm{~min}$, respectively, in HBSS containing 2 mM EDTA. Then, pieces of intestinal tissue were washed twice in HBSS and digested in RPMI medium containing $10 \% \mathrm{FBS}$, collagenase 8 ( $1 \mathrm{mg} / \mathrm{ml}$; Sigma-Aldrich), and DNAse I (30 ng/ml). Tissue was homogenized in $\mathrm{C}$ tube and gentleMACS Dissociator. Light density cells were purified by centrifugation on a 70 to $40 \%$ Percoll gradient. For isolation of cells from the lung, perfused organs were cut into small pieces and digested for $40 \mathrm{~min}$ at $37^{\circ} \mathrm{C}$ with a mixture of type IV collagenase (Worthington Biochemical) and DNase I in RPMI medium containing $2 \%$ FBS on a shaker. Tissue was homogenized in $\mathrm{C}$ tube and gentleMACS Dissociator.

\section{Flow cytometry}

For surface staining, cells were preincubated with anti-Fc receptor antibody (clone 2.4G2) and stained with appropriate antibodies in phosphate-buffered saline containing $5 \mathrm{mM}$ EDTA and 2\% FBS at $4^{\circ} \mathrm{C}$ for $25 \mathrm{~min}$. Viability was assessed by staining with $4^{\prime}, 6$-diamidino2-phenylindole (Thermo Fisher Scientific) or Fixable LIVE/DEAD Blue or Aqua Cell Stain (Molecular Probes). For intracellular cytokine staining, cells were stained with antibodies against surface markers and then fixed with $2 \%(\mathrm{w} / \mathrm{v})$ paraformaldehyde for $12 \mathrm{~min}$ at $25^{\circ} \mathrm{C}$ and permeabilized using Permeabilization Buffer (Invitrogen). Cells were subsequently stained with anti-IFN- $\gamma$ antibody for $60 \mathrm{~min}$ at $4^{\circ} \mathrm{C}$. For intranuclear staining, cells were stained with antibodies against the specified surface markers, and fixation-permeabilization was performed using the Transcription Factor Kit (Invitrogen) according to the manufacturer's instructions. Flow cytometry was performed on fluorescence-activated cell sorting (FACS) LSRII or LSRFortessa X-20 systems (BD Biosciences), and data were analyzed with FlowJo software (FlowJo LLC). Doublets and dead cells were excluded from analyses. For the analysis of DCs, neutrophils, $B$ cells, T cells, and NK cells were gated out using a Lin $^{-}$gate $\left(\mathrm{CD}^{-}\right.$, $\mathrm{CD}^{-} 9^{-}, \mathrm{CD}_{161^{-}}$, and $\mathrm{Ly}_{-} 6 \mathrm{G}^{-}$). For the analysis of skin T cells, $\mathrm{MHCII}^{+}$cells, $\mathrm{CD} 11 \mathrm{~b}^{+}$myeloid cells, neutrophils, and NK cells were systematically gated out using a $\mathrm{Lin}^{-}$gate $\left(\mathrm{MHCII}^{-}, \mathrm{CD}_{11 \mathrm{~b}}^{-}, \mathrm{CD}^{-} 61^{-}\right.$, and $\mathrm{Ly}-6 \mathrm{G}^{-}$). Antibodies used are listed in table S1. Biotin-conjugated antibodies were detected using streptavidin-conjugated Brillant UltraViolet 395 (BUV395), R-phycoerythrin-CF594 (PE-CF594) or R-phycoerythrin-cyanine dye Cy7 (PE-Cy7) (BD Biosciences). The gating strategies for DC subsets, $B$ cells, and neutrophils on Figs. 1 and 2 (B to D and G to I) and fig. S3 (A to C and G to I) are shown in fig. S2 (A and B).

\section{OT-I T cell transfer and analysis of OT-I proliferation}

OT-I naïve $\mathrm{CD}^{+} \mathrm{T}$ cells were isolated from LNs and the spleen of 6- to 12-week-old CD45.1/CD45.2 OT-I mice, using a negative CD8 isolation kit (Invitrogen). T cells were stained with $5 \mu \mathrm{M}$ CellTrace Violet (CTV; Molecular Probes). To analyze OVA cross-presentation in the K5.mOVA model, $1 \times 10^{6}$ or $2.5 \times 10^{6}$ naïve OT-I T cells were transferred intravenously. Proliferation of OT-I T cells in CLNs (corresponding to a pool of inguinal, auricular, and brachial LN unless specified) and skin infiltration were analyzed either 60 hours or 8 to 11 days later using flow cytometry. OT-I T cells were identified on the basis of their $\mathrm{Lin}^{-} \mathrm{TCR} \beta^{+} \mathrm{CD} 5^{+} \mathrm{CD} 8^{+} \mathrm{V} \alpha 2^{+} \mathrm{V} \beta 5.1 / 2^{+} \mathrm{CD} 45.1^{+} \mathrm{CD} 45.2^{+}$ phenotype. Proliferation, replication, and expansion indexes were calculated using FloJo software (FlowJo LLC).

\section{Assay for the in vitro suppressive capacity of $\mathrm{T}_{\text {reg }}$ cells}

Mouse LN and spleen single-cell suspensions were enriched for $\mathrm{CD} 4{ }^{+} \mathrm{T}$ cells by negative CD 4 isolation (Invitrogen). Cells were stained with monoclonal antibody (mAb) to CD5, CD4, and CD25, as detailed above. $\mathrm{CD} 4^{+} \mathrm{CD} 25^{+} \mathrm{T}_{\text {reg }}$ cells from CTRL and $X c r 1^{\mathrm{Ab} 1}$ mice and conventional $\mathrm{CD} 4^{+} \mathrm{CD} 25^{-} \mathrm{T}$ cells (responder) were sorted using a FACSAria Special Order Research Product (BD Biosciences). Cell purity was $>98 \%$. CD $4^{+} \mathrm{CD} 25^{-} \mathrm{T}$ cells were labeled with $5 \mu \mathrm{M} \mathrm{CTV}$ (Molecular Probes). CD $4^{+} \mathrm{CD} 25^{-}$WT T cells $\left(5 \times 10^{4}\right.$ cells per well) were cultured in 96-well U-bottom plates with or without $\mathrm{T}_{\text {reg }}$ cells at responder to $\mathrm{T}_{\text {reg }}$ ratios of 1:0, 1:1, 1:2, 2:1, 4:4, 8:1, and 16:1 in the presence of irradiated ( 25 gray) syngeneic T cell-depleted splenocytes $\left(5 \times 10^{4}\right.$ cells per well) (Corning) and anti-CD $3 \varepsilon \mathrm{mAb}(0.5 \mu \mathrm{g} / \mathrm{ml}$; clone 145-2C11, EXBIO). Cells were collected after 60 hours, and 
cell division was measured by assessing relative CTV dilution on a Fortessa X20 systems (BD Biosciences).

\section{Ex vivo restimulation of OT-I T cells}

For intracellular cytokine staining, cells from the CLN or skin were isolated 60 hours or 8 to 11 days after adoptive transfer of OT-I T cells. Cells were cultured for 4 hours in RPMI 1640 plus $10 \%$ FBS containing OVA peptide (257 to 264$)(1 \mu \mathrm{g} / \mathrm{ml})$. Brefeldin A (10 mg/ml) was added after the first hour of culture. Then, cells were surface stained to identify OT-I ( $\mathrm{Lin}^{-} \mathrm{TCR} \beta^{+} \mathrm{CD} 5^{+} \mathrm{CD} 8^{+} \mathrm{V} \alpha 2^{+} \mathrm{V} \beta 5.1 / 2^{+} \mathrm{CD} 45.1^{+} \mathrm{CD} 45.2^{+}$) cells and subsequently stained intracellularly with anti-IFN- $\gamma$ antibody.

\section{Lymphocyte sequestration in the CLN}

Mice received an intraperitoneal injection of $100 \mu \mathrm{g}$ of FTY-720 (Cayman Chemical Company) as specified.

\section{Histology}

Biopsies from the skin of the back or the esophagus were incubated for $45 \mathrm{~min}$ at $4^{\circ} \mathrm{C}$ with Antigenfix (Diapath) washed with $0.1 \mathrm{M}$ phosphate-buffered saline ( $\mathrm{pH} 7.4$ ) for $45 \mathrm{~min}$ at $4^{\circ} \mathrm{C}$ and subsequently with $30 \%(\mathrm{w} / \mathrm{v})$ sucrose for 12 hours at $4^{\circ} \mathrm{C}$ and subsequently embedded in Tissue-Tek optimum cutting temperature (O.C.T., Sakura), snap-frozen, and stored at $-20^{\circ} \mathrm{C}$ until use. Eight-micrometer cryosections of the skin were cut using a cryostat (Jung Frigocut CM35000 S, Leica). Sections were stained with hematoxylin and eosin (H\&E).

Small intestine biopsies were fixed in $10 \%$ neutral buffered formalin (Microm Microtech) for 24 hours, dehydrated, and embedded in paraffin (Thermo Fisher Scientific). Microtome sections (Leica RM2245, Leica) of $3.5 \mu \mathrm{m}$ were stained (H\&E) staining using Leica Autostainer XL (Leica). Slides were mounted with Entellan (VWR) and kept at room temperature.

\section{Statistical analyses}

Statistical significance was determined using two-tailed Student's $t$ tests with Welch's correction, one- or two-way analysis of variance (ANOVA) test, with or without Sidak correction for multiple testing, or log rank (Mantel-Cox) as specified in individual figure legends. Points in graphs indicate either individual mice or a quadruplicate well, and lines indicate means or medians. In bar graphs, bars indicate means, and error bars indicate SD. Analysis was performed using GraphPad Prism software. $P<0.05$ was considered statistically significant.

\section{SUPPLEMENTARY MATERIALS}

immunology.sciencemag.org/cgi/content/full/5/45/eaba1896/DC1

Fig. S1. Expression of the mTFP1 fluorescent reporter and Cre activity are restricted to CDC1 of Xcr ${ }^{\text {Cre-mTFP1 }}$ mice.

Fig. S2. Gating strategies used for identifying the myeloid cell subsets found in the spleen, gut, skin, CLN, and lung.

Fig. S3. Absence of $\mathrm{MHCll}$ on $\mathrm{CDC1}$ s results in a higher frequency of effector memory $\mathrm{CD} 8^{+}$ T cells in the CLN and lung.

Fig. S4. $\mathrm{CCr}^{\mathrm{DTA}}$ mice permit constitutive $\mathrm{CDC} 1$ ablation.

Table S1. List of antibodies used in the study.

Data file S1. Raw data.

References (49-51)

View/request a protocol for this paper from Bio-protocol.

\section{REFERENCES AND NOTES}

1. M. Guilliams, C.-A. Dutertre, C. L. Scott, N. McGovern, D. Sichien, S. Chakarov, S. Van Gassen, J. Chen, M. Poidinger, S. De Prijck, S. J. Tavernier, I. Low, S. E. Irac, C. N. Mattar,
H. R. Sumatoh, G. H. L. Low, T. J. K. Chung, D. K. H. Chan, K. K. Tan, T. L. K. Hon, E. Fossum, B. Bogen, M. Choolani, J. K. Y. Chan, A. Larbi, H. Luche, S. Henri, Y. Saeys, E. W. Newell, B. N. Lambrecht, B. Malissen, F. Ginhoux, Unsupervised high-dimensional analysis aligns dendritic cells across tissues and species. Immunity 45, 669-684 (2016).

2. D. S. Leventhal, D. C. Gilmore, J. M. Berger, S. Nishi, V. Lee, S. Malchow, D. E. Kline, J. Kline, D. J. Vander Griend, H. Huang, N. D. Socci, P. A. Savage, Dendritic cells coordinate the development and homeostasis of organ-specific regulatory T cells. Immunity 44, 847-859 (2016).

3. A. G. Levine, S. Hemmers, A. P. Baptista, M. Schizas, M. B. Faire, B. Moltedo, C. Konopacki, M. Schmidt-Supprian, R. N. Germain, P. M. Treuting, A. Y. Rudensky, Suppression of lethal autoimmunity by regulatory $T$ cells with a single TCR specificity. J. Exp. Med. 214, 609-622 (2017).

4. V. Durai, K. M. Murphy, Functions of murine dendritic cells. Immunity 45, 719-736 (2016).

5. H. Azukizawa, H. Kosaka, S. Sano, W. R. Heath, I. Takahashi, X. H. Gao, Y. Sumikawa, M. Okabe, K. Yoshikawa, S. Itami, Induction of T-cell-mediated skin disease specific for antigen transgenically expressed in keratinocytes. Eur. J. Immunol. 33, 1879-1888 (2003).

6. S. Bedoui, P. G. Whitney, J. Waithman, L. Eidsmo, L. Wakim, I. Caminschi, R. S. Allan, M. Wojtasiak, K. Shortman, F. R. Carbone, A. G. Brooks, W. R. Heath, Cross-presentation of viral and self antigens by skin-derived $\mathrm{CD} 103^{+}$dendritic cells. Nat. Immunol. 10, 488-495 (2009).

7. S. Henri, L. F. Poulin, S. Tamoutounour, L. Ardouin, M. Guilliams, B. de Bovis, E. Devilard, C. Viret, H. Azukizawa, A. Kissenpfennig, B. Malissen, $\mathrm{CD} 207^{+} \mathrm{CD} 103^{+}$dermal dendritic cells cross-present keratinocyte-derived antigens irrespective of the presence of Langerhans cells. J. Exp. Med. 207, 189-206 (2010).

8. J. Waithman, R. S. Allan, H. Kosaka, H. Azukizawa, K. Shortman, M. B. Lutz, W. R. Heath, F. R. Carbone, G. T. Belz, Skin-derived dendritic cells can mediate deletional tolerance of class I-restricted self-reactive T cells. J. Immunol. 179, 4535-4541 (2007).

9. L. Ardouin, H. Luche, R. Chelbi, S. Carpentier, A. Shawket, F. Montanana Sanchis, C. Santa Maria, P. Grenot, Y. Alexandre, C. Gregoire, A. Fries, T.-P. Vu Manh, S. Tamoutounour, K. Crozat, E. Tomasello, A. Jorquera, E. Fossum, B. Bogen, H. Azukizawa, M. Bajenoff, S. Henri, M. Dalod, B. Malissen, Broad and largely concordant molecular changes characterize tolerogenic and immunogenic dendritic cell maturation in thymus and periphery. Immunity 45, 305-318 (2016).

10. K. Crozat, R. Guiton, V. Contreras, V. Feuillet, C.-A. Dutertre, E. Ventre, T.-P. Vu Manh, T. Baranek, A. K. Storset, J. Marvel, P. Boudinot, A. Hosmalin, I. Schwartz-Cornil, M. Dalod, The XC chemokine receptor 1 is a conserved selective marker of mammalian cells homologous to mouse CD8 $\alpha^{+}$dendritic cells. J. Exp. Med. 207, 1283-1292 (2010).

11. B. G. Dorner, M. B. Dorner, X. Zhou, C. Opitz, A. Mora, S. Güttler, A. Hutloff, H. W. Mages, K. Ranke, M. Schaefer, R. S. Jack, V. Henn, R. A. Kroczek, Selective expression of the chemokine receptor XCR1 on cross-presenting dendritic cells determines cooperation with $\mathrm{CD}^{+} \mathrm{T}$ cells. Immunity 31, 823-833 (2009).

12. Y. O. Alexandre, S. Ghilas, C. Sanchez, A. Le Bon, K. Crozat, M. Dalod, $X C R 1^{+}$dendritic cells promote memory $\mathrm{CD}^{+} \mathrm{T}$ cell recall upon secondary infections with Listeria monocytogenes or certain viruses. J. Exp. Med. 213, 75-92 (2016).

13. J. P. Böttcher, E. Bonavita, P. Chakravarty, H. Blees, M. Cabeza-Cabrerizo, S. Sammicheli, N. C. Rogers, E. Sahai, S. Zelenay, C. Reis e Sousa, NK cells stimulate recruitment of CDC1 into the tumor microenvironment promoting cancer immune control. Cell 172, 1022-1037.e14 (2018).

14. A. Brewitz, S. Eickhoff, S. Dähling, T. Quast, S. Bedoui, R. A. Kroczek, C. Kurts, N. Garbi, W. Barchet, M. lannacone, F. Klauschen, W. Kolanus, T. Kaisho, M. Colonna, R. N. Germain, W. Kastenmüller, $C D 8^{+} \mathrm{T}$ cells orchestrate $\mathrm{PDC}-\mathrm{XCR} 1^{+}$dendritic cell spatial and functional cooperativity to optimize priming. Immunity 46, 205-219 (2017).

15. T. Ohta, M. Sugiyama, H. Hemmi, C. Yamazaki, S. Okura, I. Sasaki, Y. Fukuda, T. Orimo, K. J. Ishii, K. Hoshino, F. Ginhoux, T. Kaisho, Crucial roles of XCR1-expressing dendritic cells and the XCR1XCL1 chemokine axis in intestinal immune homeostasis. Sci. Rep. 6, 23505 (2016).

16. B. Becher, A. Waisman, L.-F. Lu, Conditional gene-targeting in mice: Problems and solutions. Immunity 48, 835-836 (2018).

17. K. Hashimoto, S. K. Joshi, P. A. Koni, A conditional null allele of the major histocompatibility IA-beta chain gene. Genesis 32, 152-153 (2002).

18. S. Mundt, D. Mrdjen, S. G. Utz, M. Greter, B. Schreiner, B. Becher, Conventional DCs sample and present myelin antigens in the healthy CNS and allow parenchymal T cell entry to initiate neuroinflammation. Sci. Immunol. 4, eaau8380 (2019).

19. S. Muth, K. Schutze, H. Schild, H. C. Probst, Release of dendritic cells from cognate CD4 ${ }^{+}$ T-cell recognition results in impaired peripheral tolerance and fatal cytotoxic T-cell mediated autoimmunity. Proc. Natl. Acad. Sci. U.S.A. 109, 9059-9064 (2012).

20. H. A. Bolton, E. Zhu, A. M. Terry, T. V. Guy, W.-P. Koh, S.-Y. Tan, C. A. Power, P. Bertolino, K. Lahl, T. Sparwasser, E. Shklovskaya, B. Fazekas de St Groth, Selective Treg reconstitution during lymphopenia normalizes DC costimulation and prevents graft-versus-host disease. J. Clin. Invest. 125, 3627-3641 (2015).

21. M. Danilo, V. Chennupati, J. G. Silva, S. Siegert, W. Held, Suppression of Tcf1 by inflammatory cytokines facilitates effector CD8 T cell differentiation. Cell Rep. 22, 2107-2117 (2018). 
22. N. Wang, M. Keszei, P. Halibozek, B. Yigit, P. Engel, C. Terhorst, Slamf6 negatively regulates autoimmunity. Clin. Immunol. 173, 19-26 (2016).

23. M. Matloubian, C. G. Lo, G. Cinamon, M. J. Lesneski, Y. Xu, V. Brinkmann, M. L. Allende, R. L. Proia, J. G. Cyster, Lymphocyte egress from thymus and peripheral lymphoid organs is dependent on S1P receptor 1. Nature 427, 355-360 (2004).

24. L. Madsen, N. Labrecque, J. Engberg, A. Dierich, A. Svejgaard, C. Benoist, D. Mathis, L. Fugger, Mice lacking all conventional MHC class II genes. Proc. Natl. Acad. Sci. U.S.A. 96, 10338-10343 (1999).

25. K. Hochweller, G. H. Wabnitz, Y. Samstag, J. Suffner, G. J. Hämmerling, N. Garbi, Dendritic cells control T cell tonic signaling required for responsiveness to foreign antigen. Proc. Natl. Acad. Sci. U.S.A. 107, 5931-5936 (2010).

26. K. A. Hogquist, S. C. Jameson, The self-obsession of T cells: How TCR signaling thresholds affect fate 'decisions' and effector function. Nat. Immunol. 15, 815-823 (2014).

27. I. Stefanová, J. R. Dorfman, R. N. Germain, Self-recognition promotes the foreign antigen sensitivity of naive T lymphocytes. Nature 420, 429-434 (2002).

28. T. Chinen, P. Y. Volchkov, A. V. Chervonsky, A. Y. Rudensky, A critical role for regulatory T cell-mediated control of inflammation in the absence of commensal microbiota. J. Exp. Med. 207, 2323-2330 (2010).

29. J. Yi, J. Jung, S.-W. Hong, J. Y. Lee, D. Han, K. S. Kim, J. Sprent, C. D. Surh, Unregulated antigen-presenting cell activation by $\mathrm{T}$ cells breaks self tolerance. Proc. Natl. Acad. Sci. U.S.A. 116, 1007-1016 (2019).

30. J. Liu, X. Cao, Regulatory dendritic cells in autoimmunity: A comprehensive review. J. Autoimmun. 63, 1-12 (2015).

31. Y. Maeda, H. Nishikawa, D. Sugiyama, D. Ha, M. Hamaguchi, T. Saito, M. Nishioka, J. B. Wing, D. Adeegbe, I. Katayama, S. Sakaguchi, Detection of self-reactive CD8 ${ }^{+}$T cells with an anergic phenotype in healthy individuals. Science 346, 1536-1540 (2014).

32. O. S. Qureshi, Y. Zheng, K. Nakamura, K. Attridge, C. Manzotti, E. M. Schmidt, J. Baker, L. E. Jeffery, S. Kaur, Z. Briggs, T. Z. Hou, C. E. Futter, G. Anderson, L. S. K. Walker, D. M. Sansom, Trans-endocytosis of CD80 and CD86: A molecular basis for the cellextrinsic function of CTLA-4. Science 332, 600-603 (2011).

33. J. Loschko, H. A. Schreiber, G. J. Rieke, D. Esterházy, M. M. Meredith, V. A. Pedicord, K.-H. Yao, S. Caballero, E. G. Pamer, D. Mucida, M. C. Nussenzweig, Absence of MHC class II on CDCs results in microbial-dependent intestinal inflammation. J. Exp. Med. 213, 517-534 (2016).

34. W. Yu, N. Jiang, P. J. R. Ebert, B. A. Kidd, S. Müller, P. J. Lund, J. Juang, K. Adachi, T. Tse, M. E. Birnbaum, E. W. Newell, D. M. Wilson, G. M. Grotenbreg, S. Valitutti, S. R. Quake, M. M. Davis, Clonal deletion prunes but does not eliminate self-specific $\alpha \beta C D 8^{+} T$ lymphocytes. Immunity 42, 929-941 (2015).

35. F. P. Legoux, J.-B. Lim, A. W. Cauley, S. Dikiy, J. Ertelt, T. J. Mariani, T. Sparwasser, S. S. Way, J. J. Moon, $\mathrm{CD}^{+} \mathrm{T}$ cell tolerance to tissue-restricted self antigens is mediated by antigen-specific regulatory $T$ cells rather than deletion. Immunity 43, 896-908 (2015).

36. J. K. Broom, A. M. Lew, H. Azukizawa, T. J. Kenna, G. R. Leggatt, I. H. Frazer, Antigen-specific CD4 cells assist CD8 T-effector cells in eliminating keratinocytes. J. Invest. Dermatol. 130, 1581-1589 (2010)

37. J.D. Mintern, G. M. Davey, G. T. Belz, F. R. Carbone, W. R. Heath, Cutting edge: Precursor frequency affects the helper dependence of cytotoxic T cells. J. Immunol. 168, 977-980 (2002).

38. H. Azukizawa, S. Sano, H. Kosaka, Y. Sumikawa, S. Itami, Prevention of toxic epidermal necrolysis by regulatory T cells. Eur. J. Immunol. 35, 1722-1730 (2005).

39. B. Vander Lugt, J. Riddell, A. A. Khan, J. A. Hackney, J. Lesch, J. DeVoss, M. T. Weirauch, H. Singh, I. Mellman, Transcriptional determinants of tolerogenic and immunogenic states during dendritic cell maturation. J. Cell Biol. 216, 779-792 (2017).

40. T. Ahrends, A. Spanjaard, B. Pilzecker, N. Babala, A. Bovens, Y. Xiao, H. Jacobs, J. Borst, $\mathrm{CD} 4^{+} \mathrm{T}$ cell help confers a cytotoxic $\mathrm{T}$ cell effector program including coinhibitory receptor downregulation and increased tissue invasiveness. Immunity 47, 848-861.e5 (2017).

41. H. Luche, O. Weber, T. Nageswara Rao, C. Blum, H. J. Fehling, Faithful activation of an extra-bright red fluorescent protein in "knock-in" Cre-reporter mice ideally suited for lineage tracing studies. Eur. J. Immunol. 37, 43-53 (2007).
42. D. Voehringer, H.-E. Liang, R. M. Locksley, Homeostasis and effector function of lymphopenia-induced "memory-like" $\mathrm{T}$ cells in constitutively T cell-depleted mice. J. Immunol. 180, 4742-4753 (2008).

43. K. A. Hogquist, S. C. Jameson, W. R. Heath, J. L. Howard, M. J. Bevan, F. R. Carbone, T cell receptor antagonist peptides induce positive selection. Cell 76, 17-27 (1994).

44. D. R. Shimshek, J. Kim, M. R. Hübner, D. J. Spergel, F. Buchholz, E. Casanova, A. F. Stewart, P. H. Seeburg, R. Sprengel, Codon-improved Cre recombinase (iCre) expression in the mouse. Genesis 32, 19-26 (2002).

45. H.-w. Ai, J. N. Henderson, S. J. Remington, R. E. Campbell, Directed evolution of a monomeric, bright and photostable version of Clavularia cyan fluorescent protein: Structural characterization and applications in fluorescence imaging. Biochem. J. 400, 531-540 (2006)

46. S. J. Pettitt, Q. Liang, X. Y. Rairdan, J. L. Moran, H. M. Prosser, D. R. Beier, K. C. Lloyd, A. Bradley, W. C. Skarnes, Agouti C57BL/6N embryonic stem cells for mouse genetic resources. Nat. Methods 6, 493-495 (2009).

47. C. I. Rodriguez, F. Buchholz, J. Galloway, R. Sequerra, J. Kasper, R. Ayala, A. F. Stewart, S. M. Dymecki, High-efficiency deleter mice show that FLPe is an alternative to Cre-loxP. Nat. Genet. 25, 139-140 (2000)

48. N. Bouladoux, C. Hennequin, C. Malosse, B. Malissen, Y. Belkaid, S. Henri, Hapten-specific T cell-mediated skin inflammation: Flow cytometry analysis of mouse skin inflammatory infiltrate. Methods Mol. Biol. 1559, 21-36 (2017).

49. A. Bachem, E. Hartung, S. Güttler, A. Mora, X. Zhou, A. Hegemann, M. Plantinga, E. Mazzini, P. Stoitzner, S. Gurka, V. Henn, H. W. Mages, R. A. Kroczek, Expression of XCR1 characterizes the Batf3-dependent lineage of dendritic cells capable of antigen cross-presentation. Front. Immunol. 3, 214 (2012)

50. L. Bar-On, T. Birnberg, K. L. Lewis, B. T. Edelson, D. Bruder, K. Hildner, J. Buer, K. M. Murphy, B. Reizis, $\mathrm{S}$. Jung, $\mathrm{CX}_{3} \mathrm{CR}^{+}{ }^{+} \mathrm{CD} 8 \alpha^{+}$dendritic cells are a steady-state population related to plasmacytoid dendritic cells. Proc. Natl. Acad. Sci. U.S.A. 107, 14745-14750 (2010).

51. B. Malissen, S. Tamoutounour, S. Henri, The origins and functions of dendritic cells and macrophages in the skin. Nat. Rev. Immunol. 14, 417-428 (2014).

Acknowledgments: We thank H. Azukizawa for the K5.mOVA mice; N. Philippe for blastocyst microinjection; K. Djenad, H. Luche, and S. Tamoutounour for help in characterizing $X_{c r 1}{ }^{\text {Cre-mTFP1 }}$ mice; C. Pierini-Malosse for technical assistance; the CIML flow cytometry facility; and L. Chasson for histology. Funding: This work was supported by CNRS, INSERM, PHENOMIN-CIPHE, the European Research Council (ERC) under the European Union's Horizon 2020 research and innovation program [grant agreement no. 787300 (BASILIC) to B.M.], ERA-NET Infect-ERA (ABIR: ANR-13-IFEC-0005-03 to B.M.), the DCBIOL LabEx (grants ANR-11-LABEX-0043 and ANR-10-IDEX-0001-02 PSL), the $A^{*}$ Midex project (ANR-11IDEX-0001-02), and by the Fondation ARC pour la recherche sur le cancer (grant PJA 20161205004 to S.H.). C.W. is supported by a fellowship from Fondation ARC pour la recherche sur le cancer. V.L.G. is supported by a fellowship from Takeda Pharmaceuticals. Author contributions: C.W., S.H., and B.M. conceived the project. F.F. and B.M. developed the $\mathrm{X} \mathrm{Cr}{ }^{\mathrm{Cre}-\mathrm{mTFP} 1}$ mouse model. C.W. and V.L.G. performed the experiments with the technical assistance of O.V. C.W. and S.H. did the statistical analysis. C.W., S.H., and B.M. wrote the manuscript. Competing interests: The authors declare that they have no competing financial interests. Data and materials availability: All data needed to evaluate the conclusions of the paper are present in the paper or the Supplementary Materials. The $X_{\mathrm{Cr}} 1^{\mathrm{Cre}^{\text {-mTFP } 1}}$ mice strain is available to interested investigators upon request.

Submitted 12 November 2019

Accepted 18 February 2020

Published 13 March 2020

10.1126/sciimmunol.aba1896

Citation: C. Wohn, V. Le Guen, O. Voluzan, F. Fiore, S. Henri, B. Malissen, Absence of MHC class II on $\mathrm{CDC} 1$ dendritic cells triggers fatal autoimmunity to a cross-presented self-antigen. Sci. Immunol. 5, eaba1896 (2020). 


\section{ScienceImmunology}

\section{Absence of MHC class II on CDC1 dendritic cells triggers fatal autoimmunity to a cross-presented self-antigen}

Christian Wohn, Valentin Le Guen, Odessa Voluzan, Frédéric Fiore, Sandrine Henri and Bernard Malissen

Sci. Immunol. 5, eaba1896.

DOI: $10.1126 /$ sciimmunol.aba1896

\section{Cross-tolerization tale}

Conventional type 1 dendritic cells ( $\mathrm{CDC} 1 \mathrm{~s}$ ) present exogenous antigen on $\mathrm{MHCl}$ to $\mathrm{CD}^{+} \mathrm{T}$ cells through the process of cross-presentation. Wohn et al. now show that MHCII on $\mathrm{CDC} 1 \mathrm{~s}$ is required for cross-tolerization of CD8 ${ }^{+} \mathrm{T}$ cells. They developed a mouse model in which Cre recombinase is expressed under control of the CDC1 marker XC chemokine receptor (XCR1) to generate mice that are specifically lacking MHCII on CDC1 cells. MHCII-deficient CDC1s could not cross-tolerize autoreactive CD8 ${ }^{+}$T cells but instead converted them into effector $\mathrm{CD}^{+}{ }^{+}$T cells that caused a lethal autoimmune response. The ability of $\mathrm{CDC} 1 \mathrm{~s}$ to enforce cross-tolerization is not completely acquired during homeostatic maturation but requires MHCII-restricted interactions with regulatory T cells.

ARTICLE TOOLS

SUPPLEMENTARY

MATERIALS

REFERENCES http://immunology.sciencemag.org/content/5/45/eaba1896

http://immunology.sciencemag.org/content/suppl/2020/03/09/5.45.eaba1896.DC1

This article cites 51 articles, 19 of which you can access for free http://immunology.sciencemag.org/content/5/45/eaba1896\#BIBL

Use of this article is subject to the Terms of Service

Science Immunology (ISSN 2470-9468) is published by the American Association for the Advancement of Science, 1200 New York Avenue NW, Washington, DC 20005. The title Science Immunology is a registered trademark of AAAS.

Copyright $@ 2020$ The Authors, some rights reserved; exclusive licensee American Association for the Advancement of Science. No claim to original U.S. Government Works 